\title{
Comparative study on growth of leafy vegetables grown in a hybrid BFT-aquaponics using Japanese eel, Anguilla japonica and hydroponics
}

\author{
Dong-Hoon Lee', Jeong-Dae Kim ${ }^{2, *}$ \\ ${ }^{1}$ Gyeonggi Province Maritime and Fisheries Research Institute, Yangpyeong 12513, Korea \\ ${ }^{2}$ College of Animal Life Sciences, Kangwon National University, Chuncheon 24341, Korea
}

\begin{abstract}
Aquaponics is a cultivation system that combines aquaculture and agricultural hydroponics. This study investigated the productivity of leafy vegetables cultivated in the hybrid biofloc technology-aquaponics (HBFT-AP) using Japanese eel fed two kinds of diets (Mash, commercial powdered feed and extruded pellet [EP]) and hydroponics (HP).The mash was fed to the fish in a type of a dough mixed with water for 6 weeks (Exp1) and switched to the EP containing 2.7\% monobasic potassium phosphate (MKP) for subsequent 6 weeks (Exp2). Leafy vegetables of 8 cultivar were employed in the experiment and water quality [dissolved oxygen (DO, mg/L), $\mathrm{pH}$, water temperature $\left({ }^{\circ} \mathrm{C}\right)$, electrical conductivity $(\mathrm{EC} ; \mu \mathrm{s} / \mathrm{cm})$, turbidity (NTU), $\mathrm{TAN}\left(\mathrm{NH}_{3}+\mathrm{NH}_{4}^{+}\right)(\mathrm{mg} / \mathrm{L}), \mathrm{NO}_{2}-\mathrm{N}$ $(\mathrm{mg} / \mathrm{L}), \mathrm{NO}_{3}-\mathrm{N}(\mathrm{mg} / \mathrm{L})$ and $\left.\mathrm{PO}_{4}-\mathrm{P}(\mathrm{mg} / \mathrm{L})\right]$ was measured 6 times a week. Leafy vegetable productivity (HBFT-AP vs HP) was compared in respective experiment, which was similar or somewhat higher in HBFT-AP. During the 12-week feeding trial, concentrations of nitrite $\left(\mathrm{NO}_{2}-\mathrm{N}\right)$ and phosphorus $\left(\mathrm{PO}_{4}-\mathrm{P}\right)$ were kept low in variability while total ammonia nitrogen (TAN) and $\mathrm{NO}_{3}-\mathrm{N}$ levels increased with time in HBFT-AP. At the end of two feeding trials, values of weight gain (WG, \%), feed efficiency (FE, \%), specific growth rate $(\mathrm{SGR}, \%)$ and protein efficiency ratio (PER) were higher in Exp2 than in Exp1. As well, higher values in hematocrit (PCV, $\%)$, plasma $\mathrm{K}(\mathrm{mEq} / \mathrm{L})$ and inorganic phosphorus $(\mathrm{mg} / \mathrm{dL})$ were found $(p<0.05)$ in Exp2 where fish were fed the EP (EP: 38.60\%, 2.80 $\mathrm{mEq} / \mathrm{L}$ and $7.04 \mathrm{~g} / \mathrm{dL} ;$ Mash: $33.20 \%, 1.95 \mathrm{mEq} / \mathrm{L}$ and $5.50 \mathrm{~g} / \mathrm{dL}$ ). Leafy vegetables in HBFT-AP using Japanese eel fed the EP with MKP 2.7\% had a productivity similar (4 kinds of cultivar) or somewhat higher (4 kinds of cultivar) compared to those in HP. Also, Japanese eel fed the EP showed higher values of $\mathrm{Pi}(\mathrm{m} / \mathrm{dL})$ and $\mathrm{K}(\mathrm{mEq} / \mathrm{L})$ in plasma compared to those fed commercial powder diet.
\end{abstract}

Keywords: Anguilla japonica, Feeds, Aquaponics, Monobasic potassium phosphate (MKP), Hydroponics, Productivity

\footnotetext{
Received: Feb 23, 2021 Revised: Apr 27, 2021 Accepted: Jun 6, 2021

${ }^{*}$ Corresponding author: Jeong-Dae Kim

College of Animal Life Sciences, Kangwon National University, Chuncheon 24341, Korea

Tel: +82-33-250-8634, Fax: +82-33-259-5572, E-mail: menzang@gmail.com
}

This is an Open Access article distributed under the terms of the Creative Commons Attribution Non-Commercial License (http://creativecommons.org/licenses/by$\mathrm{nc} / 4.0 /$ ) which permits unrestricted non-commercial use, distribution, and reproduction in any medium, provided the original work is properly cited.

Copyright $\odot 2021$ The Korean Society of Fisheries and Aquatic Science 


\section{Introduction}

In recent years, strict regulations have been applied to protect environmental pollution by aquaculture because it is well known to be the major contributor to the increasing level of organic waste and toxic compounds in the aquatic ecosystems (NIFS, 2013). In addition, hydroponics is a technology for growing plants in nutrient solutions with or without an artificial medium to provide mechanical support. Major problems for hydroponic cultivation are higher operational cost and the generation of the pollution due to discharge of waste nutrient solution. The effluent released into the environment can have negative impacts on the surrounding ecosystems as well as the potential to contaminate the groundwater (Kumar \& Cho, 2014). For this reason, studies on the stable reuse of the drainage are currently underway (Gieling et al., 2005; Gutiérrez et al. 2008), but have not been put into practical use due to technical limitations.

To date, recirculating aquaculture system (RAS) and biofloc technology (BFT) are representative aquaculture methods without water exchange of rearing tank (Avnimelech et al., 2015; FAO, 1986). In Korea, RAS does not completely reuse water and it is common that less than $10 \%$ of the total circulating water is replenished per day (Suh et al., 2001). Russo et al. (1981) reported that RAS method may cause problems such as deterioration of fish growth and disease occurrence due to lack of dissolved oxygen (DO), increase of dissolved organic matters and accumulation of inorganic matters such as $\mathrm{NH}_{3}-\mathrm{N}$ and $\mathrm{CO}_{2}$. So, several devices (sedimentation tank, filter, rotating disc contactor, packed bed reactor, fluidized bed reactor, foam separator, UV sterilizer, etc.) are required to remove solids, $\mathrm{NH}_{3}-\mathrm{N}$ and $\mathrm{CO}_{2}$ in the system (Losordo et al., 1994; Reyes \& Lawson, 1996). However, Schneider et al. (2006) reported that industrial expansion of RAS is slow due to high initial capital investment. Therefore, there are many freshwater aquaculture farms which are operated by running water method through a simple sedimentation facility in Korea and RAS system are limited to farming of highly expensive fish such as eel. BFT (biofloc thechnology) is a method of aquaculture recycling water of fish rearing tank using equipment such as air-lift, air-stone, venturi-pump, etc. and this method was introduced in the 2000s in Korea. The pollutant such as $\mathrm{NH}_{3}-\mathrm{N}$ generated by aquatic organisms and unconsumed feed is used by heterotrophic microorganisms for cell growth and proliferation, and at this time, the microorganisms use organic carbon together. It is known that the C:N ratio for optimal growth of microorganisms is about 15:1-20:1 and because the amount of organic carbon in feed supplied to fish is insufficient to grow heterotrophic microorganisms, organic carbon must be artificially added. BFT, therefore, is a technique that maintains the water quality by inducing the formation of a microorganism (biofloc) and then feeding it back to aquatic organisms (fish and crustaceans), which is very effective in terms of cost compared to RAS (Avnimelech et al., 2015).

Japanese eel (Anguilla japonica) has been farmed for a long time in northeast Asia such as Korea, Japan, and China. In Korea, eel aquaculture production amounted to 10,873 metric tons as of 2019 year, accounting for a significant share in inland fishery production (MOF, 2019). However, the unstable price of eel fry dependent upon natural harvesting makes its successful farming difficult. Furthermore, the introduction of a RAS for high density and rapid growth of eel may cause an increase in infrastructure costs. Eel is cultured at the range of water temperature of $25^{\circ} \mathrm{C}-30^{\circ} \mathrm{C}$ throughout the year, therefore, it is applicable to the BFT aquaculture (Cho et al., 2015).

Aquaponics is a cultivation system that combines aquaculture and agricultural hydroponics. The feed is supplied for growth and survival of aquaculture organisms in the system. Various inorganic substances like ammonia and nitrates are produced through the decomposition of unconsumed feed and fecal matters by heterotrophic and autotrophic microorganisms. Plants grow by absorbing the nutrients mineralized by the microorganisms and then the purified water is returned to fish rearing tank. Therefore, aquaponics provides an eco-friendly environment that enables a continuous production of agricultural and aquatic products without exchange of cultivation water (FAO, 2014). Fish feed generally includes 13 types of nutrients (N, P, K, S, Ca, Mg, Fe, Mn, Cu, Zn, B, Mo, and $\mathrm{Al}$ ) that plants need. It could provide an enough amount of nutrients for growth of plants, but some such as $\mathrm{Ca}, \mathrm{K}$, and Fe are present in a very insufficient degree and must be added artificially (Rakocy, 2007). It was proposed for UVI (university of virgin islands) aquaponics to artificially add the insufficient nutrients such as $\mathrm{Ca}, \mathrm{K}, \mathrm{Fe}$, and $\mathrm{P}$ for optimum growth of plants, which was now universalized worldwide (Bailey \& Ferrarezi, 2017; Rakocy et al., 2006). Phosphorus (P) is one of the essential nutrients for maintaining normal life phenomena related to growth, reproduction, and health of animals and plants. Phosphorus, in the form of phosphate, plays an important role in fundamental biochemical reactions such as respiration, photosynthesis, muscle contraction, cell division, transmission of genetic information, 
and fermentation (Lall, 1991). Aquatic animals as well as land animals cannot efficiently use phosphorus in animal and vegetable resources, thus either monocalcium phosphate (MCP), dicalcium phosphate (DCP) or tricalcium phosphate (TCP) is added to the feed for their maximum growth (Kim et al., 1998). TCP found in phosphate rock and animal bones is soluble only in strong acids, so stomachless fish like carp do not use it, while being highly available by trout (Ogino et al., 1979).

Lee et al. (2019b) reported that potassium monophosphate (MKP) instead of conventional additive for $\mathrm{P}$ in diet for Far Eastern catfish (Silurus asotus) resulted in an increase in concentrations of $\mathrm{P}$ and $\mathrm{K}$ in the aquaponic system and an improvement in plant productivity. Also, Lee et al. (2019a) reported that leafy vegetables in the aquaponics had a productivity comparable to hydroponics using nutrient solution when a blend of beneficial microorganisms and feed containing MKP of $2.7 \%$ are applied in hybrid biofloc technology-aquaponics (HBFT-AP).

The purpose of this study was to investigate how dietary MKP affect the productivity of leafy vegetables in the HBFT-AP using Japanese eel and the hematological characteristics of the fish fed either a commercial powdered feed or an extruded pellet with MKP of $2.7 \%$.

\section{Materials and Methods}

\section{Experimental diet}

The extruded pellet (EP) containing MKP of $2.7 \%$ was manufactured at Sajo Dongawon dangjin feed factory (Dangjin, Korea) (Table 1). A commercial powdered feed for Japanese eel was provided by Cargill Agri Purina in Korea. Chemical composition of the diets is shown in Table 2.

\section{Experimental system configuration and operation}

The experimental production system of two cultivations, aquaponics and hydroponics is shown in Fig. 1. HBFT-AP, which combines modified BFT aquaculture with hydroponic cultivation facilities, was composed of one fish tank ( $\oint 4.5 \mathrm{~m} \times \mathrm{H} 0.7$ $\mathrm{m})$, one sump tank (L $2.0 \mathrm{~m} \times \mathrm{W} 1.0 \mathrm{~m} \times \mathrm{H} 0.9 \mathrm{~m}$ ), two-layered plant bed (L $2.9 \mathrm{~m} \times \mathrm{W} 0.6 \mathrm{~m} \times \mathrm{H} 0.1 \mathrm{~m}$ ), one bio-helix filter (680 L, Isan M Tech., Daejeon, Korea) and one pump (1.5 HP) for water circulation in the fish tank, sump tank and plant bed. Oxygen was provided by venturi air supply system and fluorescent lamps (40 ea) for light supply were installed on the first floor of the plant bed. Leafy vegetables cultivation porters consisted of a
Table 1. Ingredient composition of the experimental diets ${ }^{1)}$

\begin{tabular}{lll}
\hline Ingredient & Mash $^{1)}$ & EP \\
\hline Fish meal (Alaska) & - & 60.02 \\
Blood meal & - & 4.00 \\
Squid liver powder & - & 1.00 \\
Wheat flour & - & 19.10 \\
Dried yeast & - & 1.00 \\
Fish oil & - & 8.21 \\
Choline-liquid (50\%) & - & 0.30 \\
Liquid methionine (71.7\%) & - & 0.02 \\
Lecithin & - & 1.00 \\
Limestone-S & - & 1.00 \\
MKP & - & 2.70 \\
Salt & - & 0.30 \\
Organic Fe & - & 0.50 \\
Vitamin C & - & 0.10 \\
Vitamin E & - & 0.10 \\
Vitamin Mix & - & 0.50 \\
Mineral Mix & - & 0.10 \\
Antioxidant (BHA) & - & 0.05 \\
\hline
\end{tabular}

"Mash, commercial powdered feed (closed formulation) provided by Cargill Agri Purina, Korea; EP, extruded pellet manufactured by Sajo Dongawon, Korea.

${ }^{2)}$ Vitamin added to supply the following (per kg diet): vitamin $A, 22,000$ IU; vitamin $D_{3}, 4,400$ $\mathrm{IU}$; vitamin $\mathrm{E}, 320 \mathrm{IU}$; vitamin $\mathrm{K}_{3}, 24 \mathrm{mg}$; thiamine $\mathrm{HCl}, 50 \mathrm{mg}$; riboflavin, $60 \mathrm{mg}$; D-Ca pantothenate, $120 \mathrm{mg}$; biotin, $2 \mathrm{mg}$; folic acid, 20 mg; vitamin $\mathrm{B}_{12}, 100 \mathrm{mg}$; niacin, 300 $\mathrm{mg}$; pyridoxine $\mathrm{HCl}, 30 \mathrm{mg}$; inositol, $600 \mathrm{mg}$; ethoxyquin, $67 \mathrm{mg}$.

${ }^{3)}$ Mineral added to supply the following (per kg diet): copper sulfate $(25.4 \% \mathrm{Cu}), 10 \mathrm{mg}$; zinc sulfate ( $22.7 \% \mathrm{Zn}), 60 \mathrm{mg}$; manganous sulfate ( $32.5 \% \mathrm{Mn}), 50 \mathrm{mg}$; magnesium sulfate $(24.3 \% \mathrm{Mg})$, cobalt chloride $(24.8 \% \mathrm{Co}), 2 \mathrm{mg}$; potassium iodide $(76.4 \% \mathrm{l}), 2.0 \mathrm{mg}$; sodium selenite ( $45.6 \% \mathrm{Se}), 0.75 \mathrm{mg}$.

MKP, monobasic potassium phosphate; BHA, butyl hydroxyl anisole.

Table 2. Chemical composition of the experimental diets

\begin{tabular}{lll}
\hline Composition (\%) & Mash & EP \\
\hline Moisture (\%) & 6.56 & 3.95 \\
Crude protein (\%) & 51.70 & 47.27 \\
Crude lipid (\%) & 5.01 & 12.60 \\
Crude ash (\%) & 12.81 & 16.37 \\
Crude fiber (\%) & 0.44 & 0.67 \\
Ca (\%) & 3.81 & 4.67 \\
P (\%) & 2.11 & 3.02 \\
Mg (ppm) & $1,018.13$ & $1,932.09$ \\
Fe (ppm) & 402.19 & 542.26 \\
Cu (ppm) & 4.43 & 12.23 \\
Mn (ppm) & 16.60 & 29.84 \\
Zn (ppm) & 222.28 & 105.73 \\
K (ppm) & $5,243.51$ & $8,774.59$ \\
\hline
\end{tabular}

Values are means of 2 determinations: Mash, commercial powdered feed; EP, extruded pellet. 
(A)

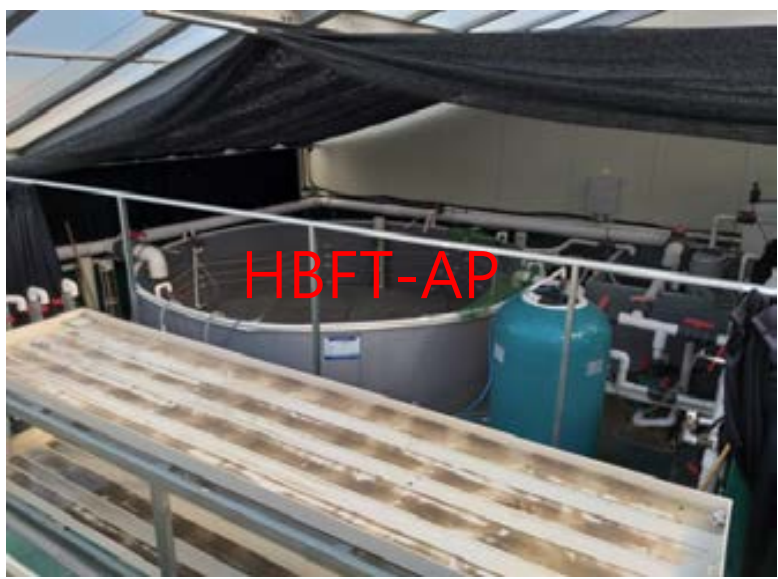

(B)

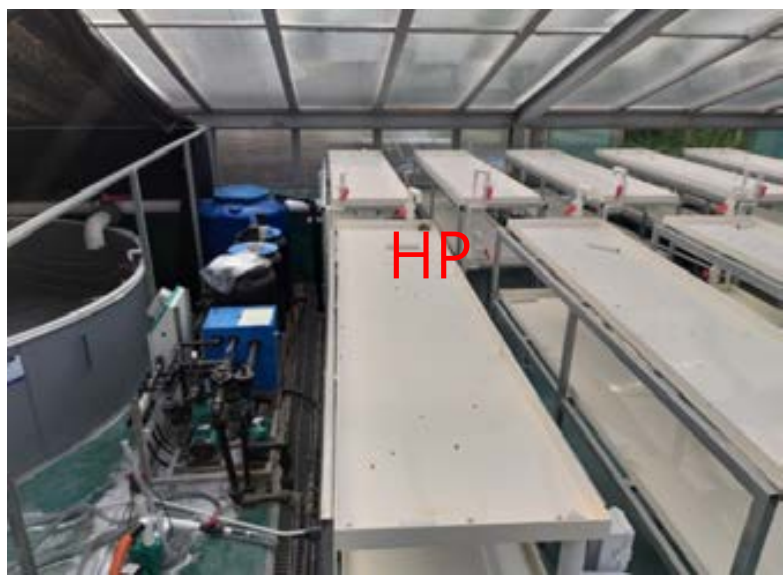

Fig. 1. Compartments and water flow of the experimental design. (A) HBFT-AP (hybrid biofloc technology-aquaponics) system: fish tank $(\oint 4.5 \mathrm{~m}) \rightarrow \operatorname{sump} \operatorname{tank}(2 \times 1 \mathrm{~m}) \rightarrow \operatorname{pump}(1.5 \mathrm{HP}) \rightarrow$ biohelix filter $(680 \mathrm{~L}) \rightarrow$ vegetable bed $(2.9 \times 0.6 \times 0.1 \mathrm{~m}$, No. 20$) \rightarrow$ fish tank; (B) HP (hydroponics): nutrient solution tank $\rightarrow$ pump $(1 \mathrm{HP}) \rightarrow \operatorname{sump} \operatorname{tank}(1 \times 0.5 \times 1 \mathrm{~m}) \rightarrow \operatorname{pump}(1.5 \mathrm{HP}) \rightarrow \operatorname{vegetable}$ bed $(2.9$ $\times 0.6 \times 0.1 \mathrm{~m}$, No. 20$) \rightarrow$ sump tank.

total of 900 sites with 45 sites per plant bed, and a $25 \mathrm{~mm}$ PVC pipe for water supply and a $40 \mathrm{~mm}$ PVC pipe for water drainage were employed to aquaponics plant bed. Finally a $100 \mathrm{~mm}$ PVC pipe was used to collect plant cultivation water and flow back into the fish tank. The hydroponic system as a control group consisted of one raw water tank (1 ton), one nutrient solution automatic regulator (Nutrient system Agronic 54 model, Hangaramponics, Sangju, Korea), three nutrient solution (A, B, and $\mathrm{C}$ solution) container ( 0.1 ton per one container), one sump $\operatorname{tank}(\mathrm{L} 1.0 \mathrm{~m} \times \mathrm{W} 0.5 \mathrm{~m} \times \mathrm{H} 1 \mathrm{~m})$, and one circulation pump (1.5 HP) to supply nutrient solution to the plant bed. The composition of the culture solution for each nutrient container is shown in Table 3.

\section{Experimental fish and design}

Japanese eel (Anguilla japonica) of 367 with a mean body weight of $224 \mathrm{~g}$ were purchased from a fish farm located in Gyeonggi-province. Fish were adapted to a rearing tank of the experimental station for 1 month, during which they were fed the experimental EP diet, and then moved to the rearing tank ( $\oint 4.5$ $\mathrm{m} \times \mathrm{H} 0.7 \mathrm{~m}$ ) of the HBFT-AP. After a 24 hour fasting before the trial, total and individual weights of 50 sampled fish were measured. A type of dough made by mixing the powdered feed (Mash) with water at the ratio of 2:1 was supplied to the experimental fish for first 6 weeks (Exp1) and then switched to EP for subsequent 6 weeks (Exp2). Feeding rate (\% dry diet) of two diets was restricted to around $0.5 \%$ per fish body weight once a day to exclude
Table 3. Chemical composition of nutrient solution for growth of leafy vegetables in HP

\begin{tabular}{lll}
\hline Nutrient tank & Nutrient & Weight $(\mathrm{g})$ \\
\hline A solution tank (0.1 ton) & $\mathrm{KNO}_{3}$ & 2,525 \\
& $\mathrm{Ca}\left(\mathrm{NO}_{3}\right)_{2} \cdot 4 \mathrm{H}_{2} \mathrm{O}$ & 3,540 \\
& $\mathrm{Fe}-\mathrm{EDTA}$ & 160 \\
\hline B solution tank (0.1 ton) & $\mathrm{KNO}_{3}$ & 2,525 \\
& $\mathrm{MgSO}_{4} \cdot 7 \mathrm{H}_{2} \mathrm{O}$ & 1,850 \\
& $\mathrm{H}_{3} \mathrm{BO}_{3}$ & 30 \\
$\mathrm{MnSO}_{4} \cdot 5 \mathrm{H}_{2} \mathrm{O}$ & 877 \\
& $\mathrm{ZnSO}_{4} \cdot 7 \mathrm{H}_{2} \mathrm{O}$ & 0.9 \\
& $\mathrm{CuSO}_{4} \cdot 5 \mathrm{H}_{2} \mathrm{O}$ & 0.4 \\
& $\mathrm{Na}_{2} \mathrm{MoO}_{4} \cdot 2 \mathrm{H}_{2} \mathrm{O}$ & 0.13 \\
& $\mathrm{NaCl}$ & 16.4 \\
\hline C solution tank (0.1 ton) & $\mathrm{NH}_{4} \mathrm{H}_{2} \mathrm{PO}_{4}$ & 1,380 \\
\hline
\end{tabular}

$\mathrm{HP}$, hydroponics.

an errors in plant productivity due to unconsumed feed. EP was distributed using a belt feed feeder (Fig. 2).

\section{Experimental leafy vegetables and design}

Leafy vegetables of 8 cultivar were employed in the experiment, which were grown in a greenhouse for nursery at GARES (Gyeonggi-province Agricultural REsearch and Extension services). Growth trial of the leafy vegetables (Exp1, $3^{\text {rd }}$ to $6^{\text {th }}$ weeks and Exp2, $9^{\text {th }}$ to $12^{\text {th }}$ weeks) was conducted 2 weeks after feeding trial considering the adaptation to each experimental diet for 
(A)

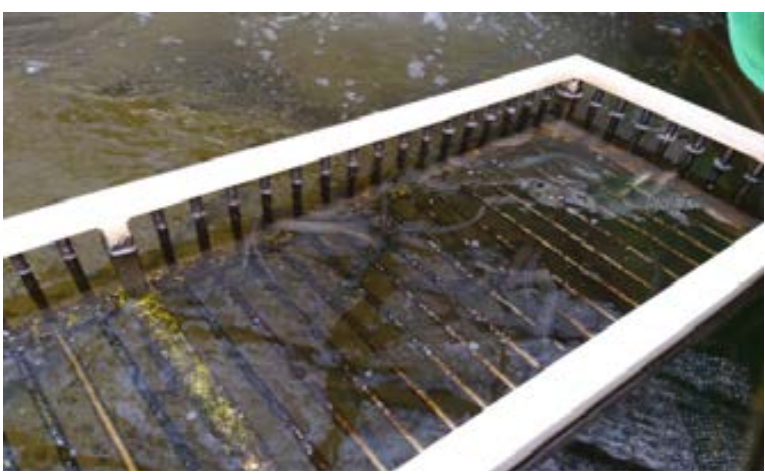

(B)

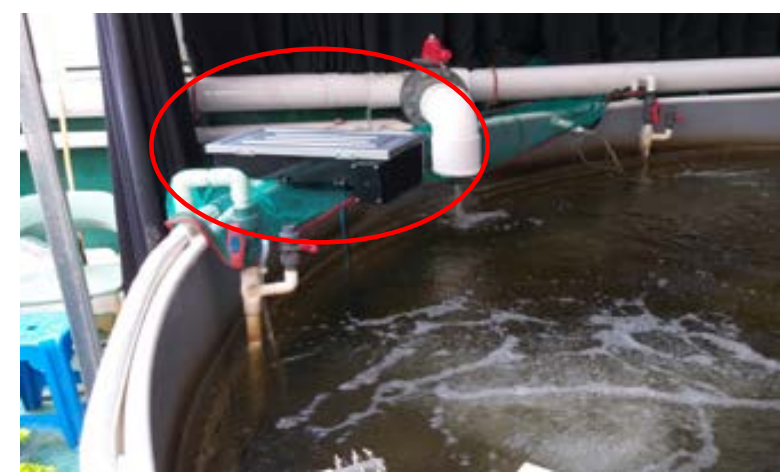

Fig. 2. Feeding of Japanese eel, Anguilla japonica for each experimental period. (A) feeding platform to provide a dough made by mixing commercial powdered feed with water $\left(1^{\text {st }}-6^{\text {th }}\right.$ weeks), (B) belt type feeder $\left(7^{\text {th }}-12^{\text {th }}\right.$ weeks) to provide extruded pellet.

fish. Five cultivar of multi green lettuce (Lactuca sativa), multi red lettuce (Lactuca sativa), Swiss chard (Beta vulgaris), abata lettuce (Lactuca sativa) and red romaine lettuce (Lactuca sativa) and five cultivar of multi green lettuce (Lactuca sativa), red lettuce (Lactuca sativa), haetsal-jeokchukmyeon lettuce (Lactuca sativa), abata lettuce (Lactuca sativa) and da-cheong-chae (Brassica campestris) were employed in Exp1 and Exp2, respectively. The leafy vegetables stocked in Exp1 were removed on the last day of the $8^{\text {th }}$ week of the Exp2, and new leafy vegetables were stocked on the first day of the $9^{\text {th }}$ week. Each of the HBFT-AP and HP groups was stocked with 900 individuals (180 individuals per cultivar), and productivity of the plants was compared 23 days after stocking.

\section{Sample measurement}

Experimental fish measurement was performed at the beginning and at the end of the experiment. Following one day fasting, the total body weight and number of fish were measured using an electronic scale (BW-1N, CAS, Yangju, Korea) after stocking at a temporarily installed net in the rearing tank. After the measurement, 50 fish were randomly sampled and anesthetized with clove oil (C8392-100mL, Sigma-Aldrich, St. Louis, MO, USA). Individual fish weight of the sampled fish was measured to find out the variation in total fish weight for experimental period. For each of leafy vegetables in Exp1 and Exp2, 12 specimens were randomly selected per leafy vegetable type, and measured by subdividing the stem, leaf number, leaf weight, root, and leaf length, respectively.

\section{Water quality management}

The method of water quality management reported by Lee et al. (2019a, b) was applied to this experiment. For the first week of feeding trial, glucose as an external organic carbon source was added to the sump tank in the HBFT-AP system together with a beneficial microorganisms (BFT-ST, EgeeTech, Irvine, CA, USA) blended of Bacillus subtilis, B. amuloliquefaciens, B. licheniformis, Cellumomona sp., Cellulomanas biazotea, Pseudomonas stutzeri, P. denitrificans, Rhodopseudomonas palustris, Nitrobacter winogradskyi and Nitrosomonas euro $\neg$ paea. Glucose inputs (650 g per $1 \mathrm{~kg}$ diet) were calculated along with feed supply following the methods described in Emerenciano et al. (2017). After the supply of the organic carbon was suspended, $\mathrm{CO}_{2}$ gas as an inorganic carbon source was supplied to the sump tank until the $\mathrm{pH}$ fell below 6.0 for two weeks. Microorganisms were added when $\mathrm{NO}_{2}-\mathrm{N}$ increased by more than 0.1 ppm and stopped when water quality maintained stable. The water containing the nutrient solution in the HP decreased due to natural evaporation and absorption of plants, thus was added from the nutrient solution supplier to the sump tank according to the decreased amount of water and nutrient solution. Water eluted from oyster shell fossils was supplied to prevent a drop in $\mathrm{pH}$ according to the accumulation of nutrient solution concentration in the sump tank, and the $\mathrm{pH}$ maintained at the range of 5-6.

\section{Water quality analysis}

Water quality $\left[\mathrm{DO}(\mathrm{mg} / \mathrm{L}), \mathrm{pH}\right.$, water temperature $\left({ }^{\circ} \mathrm{C}\right)$, electrical conductivity $(\mathrm{EC} ; \mu \mathrm{s} / \mathrm{cm})$, turbidity (NTU), TAN $\left(\mathrm{NH}_{3}\right.$ $\left.+\mathrm{NH}_{4}{ }^{+}\right)(\mathrm{mg} / \mathrm{L}), \mathrm{NO}_{2}-\mathrm{N}(\mathrm{mg} / \mathrm{L}), \mathrm{NO}_{3}-\mathrm{N}(\mathrm{mg} / \mathrm{L})$ and $\mathrm{PO}_{4}-\mathrm{P}$ $(\mathrm{mg} / \mathrm{L})]$ was measured 6 times a week. For DO, pH, water temperature, EC and turbidity, YSI PRODSS (YSI, Yellow Spring, $\mathrm{OH}, \mathrm{USA}$ ) was used, and TAN, $\mathrm{NO}_{2}-\mathrm{N}, \mathrm{NO}_{3}-\mathrm{N}$, and $\mathrm{PO}_{4}-\mathrm{P}$ 
were analyzed by colorimetric method using reagents (NitraVer ${ }^{\oplus}$ Reagent Set 2605345-KR, Low Range Ammonia Reagent Set 2604545-KR, NitriVer $\mathrm{r} 3$ Reagent Set 2608345-KR and PhosVer(r)3 Phosphater Reagent, HACH, Loveland, CO, USA) and the water quality analyzer DR5000 (HACH). In addition, trace elements in water of two systems, the HBFT-AP and HP, were analyzed: $\mathrm{K}(\mathrm{mg} / \mathrm{L}), \mathrm{Ca}(\mathrm{mg} / \mathrm{L}), \mathrm{Mg}(\mathrm{mg} / \mathrm{L}), \mathrm{Na}(\mathrm{mg} / \mathrm{L})$, Fe (mg/L), $\mathrm{Zn}(\mathrm{mg} / \mathrm{L}), \mathrm{Mn}(\mathrm{mg} / \mathrm{L})$ and $\mathrm{Cu}(\mathrm{mg} / \mathrm{L})$ using an inductively coupled plasma spectrophotometer (ICP-OES Optima 8300, Perkin Elmer, Waltham, USA), and $\mathrm{Cl}(\mathrm{mg} / \mathrm{L})$ and SO4 (mg/L) using ion chromatography (930 Comact IC Flex, Metrohm, Herisau, Switzerland).

\section{Fish blood analysis}

At the end of each fish feeding trial in HBFT-AP (Exp1 and Exp2), fish were fasted for 24 hours to investigate the changes in the blood characteristic. Anesthesia was performed with clove oil (C8392-100mL, Sigma-Aldrich), then the blood was sampled from the caudal vein of fish (each of 10 fish from two diet groups) with a $5 \mathrm{cc}$ syringe treated with heparin sodium salt from porcine intestinal mucosa (K3333-10KU, Sigma-Aldrich) for each test group (Mash and EP). Whole blood was analyzed for hemoglobin $(\mathrm{Hb}, \mathrm{g} / \mathrm{dL})$ and hematocrit (PCV, \%), and then blood plasma were obtained after centrifugation (Centrifuge 5415 R, Eppendorf, Hamburg, Germany) with conditions set at $4{ }^{\circ} \mathrm{C}, 6,500 \times \mathrm{g}$, and 10 minutes. PCV (\%) was analyzed using HAEMATOKRIT 210 (Hettich, Tuttlingen, Germany). And other blood elements such as hemoglobin $(\mathrm{Hb}, \mathrm{g} / \mathrm{dL})$, plasma glutamic oxaloacetic transaminase (GOT; U/L), glutamic pyruvic transaminase (GPT; U/L), glucose (GLU; mg/dL), inorganic phosphorus (Pi; mg/dL), Na (mEq/L), K (mEq/L) and $\mathrm{Cl}(\mathrm{mEq} /$ L) were analyzed using a blood chemical analyzer (DRI-CHEM 3500 I, Fujifilm, Tokyo, Japan) with commercial clinical investigation kit (Fuji DRI-CHEM slide, Fuji Photo Film).

\section{Statistical analysis}

Data (blood parameters, number of leaves, leaf weight and leaf length) obtained from fish and leafy vegetables growth experiment of Exp1 and Exp2 were analyzed using the one-way ANOVA of the SPSS Version 10 program, and the significance level of statistical analysis was determined at 5\% $(p<0.05)$ using Duncan's multiple range test (Duncan, 1955).

\section{Results}

\section{Water quality analysis}

The changes in water quality of the hybrid BFT aquaponic system (HBFT-AP) using microorganisms (heterotrophic and autotrophic bacteria) during the 12-week experimental period are shown in Table 4. In Exp1 (first 6 weeks), the average values measured 6 times a week were varied from 8.16 to $8.62 \mathrm{mg} / \mathrm{L}$ for DO, from 24.0 to $25.3^{\circ} \mathrm{C}$ for water temperature, from 167.4 to $335.6 \mu \mathrm{s} / \mathrm{cm}$ for $\mathrm{EC}$, from 5.81 to 8.21 for $\mathrm{pH}$, from 0.82 to 2.53 for turbidity (NTU), from 0.18 to $1.22 \mathrm{mg} / \mathrm{L}$ for TAN, from

Table 4. Change of water quality (DO, pH, temperature, EC, turbidity, $\mathrm{TAN}, \mathrm{NO}_{2}-\mathrm{N}, \mathrm{NO}_{3}-\mathrm{N}$ and $\mathrm{PO} \mathrm{O}_{4}-\mathrm{P}$ ) in $\mathrm{HBFT}-\mathrm{AP}$ for 12 weeks

\begin{tabular}{|c|c|c|c|c|c|c|c|c|c|c|}
\hline Diet & Week & $\mathrm{DO}(\mathrm{mg} / \mathrm{L})$ & $\mathrm{pH}$ & Temperature $\left({ }^{\circ} \mathrm{C}\right)$ & $\mathrm{EC}(\mu \mathrm{s} / \mathrm{cm})$ & Turbidity (NTU) & TAN (mg/L) & $\mathrm{NO}_{2}-\mathrm{N}(\mathrm{mg} / \mathrm{L})$ & $\mathrm{NO}_{3}-\mathrm{N}(\mathrm{mg} / \mathrm{L})$ & $\mathrm{PO}_{4}-\mathrm{P}(\mathrm{mg} / \mathrm{L})$ \\
\hline \multirow[t]{7}{*}{ Mash } & initial & 8.94 & 8.42 & 25.8 & 159.8 & 0.4 & 0.13 & 0.082 & 3.49 & 1.07 \\
\hline & 1 & $8.62 \pm 0.40$ & $8.21 \pm 0.12$ & $24.0 \pm 2.3$ & $167.4 \pm 6.9$ & $2.53 \pm 0.77$ & $1.14 \pm 0.86$ & $0.185 \pm 0.091$ & $2.89 \pm 0.22$ & $0.80 \pm 0.36$ \\
\hline & 2 & $8.33 \pm 0.18$ & $7.27 \pm 0.42$ & $25.3 \pm 1.0$ & $230.9 \pm 16.8$ & $1.20 \pm 0.57$ & $0.18 \pm 0.06$ & $0.118 \pm 0.047$ & $14.36 \pm 2.24$ & $4.47 \pm 0.34$ \\
\hline & 3 & $8.17 \pm 0.24$ & $6.29 \pm 0.28$ & $25.2 \pm 1.0$ & $286.9 \pm 11.6$ & $0.95 \pm 0.17$ & $0.36 \pm 0.80$ & $0.042 \pm 0.025$ & $20.50 \pm 0.81$ & $4.78 \pm 0.11$ \\
\hline & 4 & $8.16 \pm 0.28$ & $6.18 \pm 0.16$ & $25.3 \pm 1.1$ & $316.8 \pm 8.4$ & $0.82 \pm 0.24$ & $0.60 \pm 0.41$ & $0.031 \pm 0.014$ & $24.70 \pm 0.54$ & $4.98 \pm 0.07$ \\
\hline & 5 & $8.58 \pm 0.28$ & $5.95 \pm 0.03$ & $24.8 \pm 0.6$ & $320.7 \pm 1.1$ & $1.73 \pm 0.21$ & $1.18 \pm 0.21$ & $0.021 \pm 0.008$ & $25.37 \pm 0.35$ & $4.87 \pm 0.10$ \\
\hline & 6 & $8.44 \pm 0.44$ & $5.81 \pm 0.11$ & $25.0 \pm 1.3$ & $335.6 \pm 2.3$ & $1.80 \pm 0.17$ & $1.22 \pm 0.05$ & $0.018 \pm 0.002$ & $26.77 \pm 0.83$ & $4.46 \pm 0.72$ \\
\hline \multirow[t]{6}{*}{ EP } & 7 & $8.24 \pm 0.08$ & $5.53 \pm 0.04$ & $24.8 \pm 0.7$ & $337.4 \pm 5.0$ & $0.90 \pm 0.14$ & $2.11 \pm 0.03$ & $0.008 \pm 0.000$ & $24.35 \pm 0.07$ & $4.24 \pm 0.21$ \\
\hline & 8 & $8.32 \pm 0.08$ & $5.66 \pm 0.11$ & $23.8 \pm 0.0$ & $343.5 \pm 13.3$ & $1.20 \pm 0.00$ & $2.44 \pm 0.21$ & $0.018 \pm 0.001$ & $24.50 \pm 0.99$ & $4.29 \pm 1.21$ \\
\hline & 9 & $8.04 \pm 0.12$ & $5.57 \pm 0.20$ & $26.0 \pm 0.1$ & $352.8 \pm 0.21$ & $0.45 \pm 0.21$ & $2.19 \pm 0.18$ & $0.012 \pm 0.008$ & $26.90 \pm 0.14$ & $4.29 \pm 0.78$ \\
\hline & 10 & $8.41 \pm 0.06$ & $5.64 \pm 0.14$ & $24.0 \pm 0.3$ & $383.5 \pm 12.9$ & $0.95 \pm 0.10$ & $3.11 \pm 0.06$ & $0.012 \pm 0.004$ & $28.45 \pm 0.24$ & $4.84 \pm 0.28$ \\
\hline & 11 & $8.06 \pm 0.19$ & $5.53 \pm 0.07$ & $25.6 \pm 1.1$ & $422.2 \pm 8.4$ & $1.06 \pm 0.37$ & $3.14 \pm 0.04$ & $0.014 \pm 0.001$ & $31.82 \pm 1.39$ & $4.93 \pm 0.19$ \\
\hline & 12 & $8.12 \pm 0.16$ & $5.57 \pm 0.04$ & $25.6 \pm 1.0$ & $440.1 \pm 6.8$ & $0.48 \pm 0.10$ & $4.15 \pm 0.02$ & $0.014 \pm 0.002$ & $33.98 \pm 1.39$ & $4.94 \pm 0.30$ \\
\hline
\end{tabular}

Values represent the means \pm SD of the values for 7 days.

EC, electrical conductivity; TAN, total ammonia nitrogen; HBFT-AP, hybrid biofloc technology-aquaponics; Mash, commercial powdered feed; EP, extruded pellet. 
0.018 to $0.185 \mathrm{mg} / \mathrm{L}$ for nitrite $\left(\mathrm{NO}_{2}-\mathrm{N}\right)$, from 2.89 to $26.77 \mathrm{mg} /$ $\mathrm{L}$ for nitrate $\left(\mathrm{NO}_{3}-\mathrm{N}\right)$, and from 0.80 to $4.98 \mathrm{mg} / \mathrm{L}$ for phosphate $\left(\mathrm{PO}_{4}-\mathrm{P}\right)$. In Exp2 (second 6 weeks), the average values were varied from 8.04 to $8.41 \mathrm{mg} / \mathrm{L}$ for $\mathrm{DO}$, from 23.8 to $26.0^{\circ} \mathrm{C}$ for water temperature, from 337.4 to $440.1 \mu \mathrm{s} / \mathrm{cm}$ for EC, from 5.53 to 5.66 for $\mathrm{pH}$, from 0.45 to 1.20 for turbidity (NTU), from 2.11 to $4.15 \mathrm{mg} / \mathrm{L}$ for TAN, from 0.008 to $0.018 \mathrm{mg} / \mathrm{L}$ for nitrite $\left(\mathrm{NO}_{2}-\mathrm{N}\right)$, from 24.35 to $33.98 \mathrm{mg} / \mathrm{L}$ for nitrate $\left(\mathrm{NO}_{3}-\mathrm{N}\right)$, and from 4.24 to $4.94 \mathrm{mg} / \mathrm{L}$ for phosphate $\left(\mathrm{PO}_{4}-\mathrm{P}\right)$.

The changes in water quality of the hydroponic system (HP) using nutrient solution during the 12-week experimental period are shown in Table 5. Operation of the HP system began the following week after running the HBFT-AP system. In Exp1 $\left(2^{\text {nd }}\right.$ to $6^{\text {th }}$ weeks), the average values measured 6 times a week were varied from 8.84 to $9.18 \mathrm{mg} / \mathrm{L}$ for DO, from 21.1 to $23.7^{\circ} \mathrm{C}$ for water temperature, from 674.5 to $966.3 \mu \mathrm{s} / \mathrm{cm}$ for EC, from 5.42 to 5.89 for $\mathrm{pH}$, from 0.50 to 1.16 for turbidity (NTU), from 0.18 to $4.65 \mathrm{mg} / \mathrm{L}$ for TAN, from 0.006 to $0.019 \mathrm{mg} / \mathrm{L}$ for nitrite $\left(\mathrm{NO}_{2}-\mathrm{N}\right)$, from 33.17 to $47.97 \mathrm{mg} / \mathrm{L}$ for nitrate $\left(\mathrm{NO}_{3}-\mathrm{N}\right)$, and from 14.89 to $15.97 \mathrm{mg} / \mathrm{L}$ for phosphate $\left(\mathrm{PO}_{4}-\mathrm{P}\right)$. In $\operatorname{Exp} 2\left(7^{\text {th }}\right.$ to $12^{\text {th }}$ weeks), the average values were varied from 9.07 to 9.84 $\mathrm{mg} / \mathrm{L}$ for $\mathrm{DO}$, from 22.1 to $23.2^{\circ} \mathrm{C}$ for water temperature, from 762.5 to $1,320.8 \mu \mathrm{s} / \mathrm{cm}$ for $\mathrm{EC}$, from 5.32 to 6.06 for $\mathrm{pH}$, from 0.95 to 1.60 for turbidity (NTU), from 0.00 to $3.28 \mathrm{mg} / \mathrm{L}$ for TAN, from 0.005 to $0.050 \mathrm{mg} / \mathrm{L}$ for nitrite $\left(\mathrm{NO}_{2}-\mathrm{N}\right)$, from 38.80 to $55.48 \mathrm{mg} / \mathrm{L}$ for nitrate $\left(\mathrm{NO}_{3}-\mathrm{N}\right)$, and from 13.35 to $15.26 \mathrm{mg}$ / $\mathrm{L}$ for phosphate $\left(\mathrm{PO}_{4}-\mathrm{P}\right)$.

\section{Growth of leafy vegetables in HBFT-AP and HP for EXP1 and EXP2}

The productivity of leafy vegetables between HBFT-AP and HP culture systems is shown in Tables 6, 7 and Fig. 3. In Exp1, five kinds of leafy vegetables (multi-green lettuce, multi-red lettuce, Swiss chard, abata lettuce, red romaine lettuce) were cultivated for 23 days after stocking, and then growth was compared (Table $6)$. There was no significant difference in the averages of leaf number (No), leaf weight $(\mathrm{g})$, and leaf length $(\mathrm{cm})(p>0.05)$, except for leaf length (HBFT-AP, $29.12 \pm 3.38$; HP, $23.05 \pm 3.05$ $\mathrm{cm})$ of Swiss chard cultivar $(p<0.05)$. In the case of multi-green and multi-red lettuce, investigation for leaf number was not performed because it was difficult to identify the individual of the leaf due to the characteristics of cultivar (Fig. 3). In Exp2, five kinds of leafy vegetables (multi-green lettuce, red lettuce, haetsal -jeokchukmyeon lettuce, abata lettuce, da-cheong-chae) were cultivated for 23 days after stocking, and then growth was measured (Table 7). Cultivars showing the difference in leaf length $(\mathrm{cm})$ were red lettuce (HBFT-AP, $25.39 \pm 2.03$; HP, 21.93 \pm 1.23 ) and haetsal -jeokchukmyeon lettuce (HBFT-AP, 19.08 \pm 1.67 ; HP, $15.33 \pm 0.85)(p<0.05)$, and leaf weight $(\mathrm{g})$ of abata lettuce showed a significant difference between HBFT-AP (89.67 $\pm 11.33 \mathrm{~g})$ and HP $(63.61 \pm 13.15 \mathrm{~g})(p<0.05)$. In Exp2, there was no significant difference in the averaged values of leaf number (No), leaf weight $(\mathrm{g})$, and leaf length $(\mathrm{cm})(p>0.05)$, except for the three cases mentioned above.

Table 5. Change of water quality (DO, pH, temperature, EC, turbidity, $\mathrm{TAN}, \mathrm{NO}_{2}-\mathrm{N}, \mathrm{NO}_{3}-\mathrm{N}_{\text {and }} \mathrm{PO}-\mathrm{P}$ ) in $\mathrm{HP}$ for 12 weeks

\begin{tabular}{|c|c|c|c|c|c|c|c|c|c|}
\hline Week & $\mathrm{DO}(\mathrm{mg} / \mathrm{L})$ & $\mathrm{pH}$ & Temperature $\left({ }^{\circ} \mathrm{C}\right)$ & $\mathrm{EC}(\mu \mathrm{s} / \mathrm{cm})$ & Turbidity (NTU) & TAN (mg/L) & $\mathrm{NO}_{2}-\mathrm{N}(\mathrm{mg} / \mathrm{L})$ & $\mathrm{NO}_{3}-\mathrm{N}(\mathrm{mg} / \mathrm{L})$ & $\mathrm{PO}_{4}-\mathrm{P}(\mathrm{mg} / \mathrm{L})$ \\
\hline 1 & Not measured & & & & & & & & \\
\hline 2 & $9.11 \pm 0.17$ & $5.89 \pm 0.44$ & $21.1 \pm 1.0$ & $821.4 \pm 32.6$ & $0.98 \pm 0.21$ & $4.65 \pm 0.74$ & $0.016 \pm 0.006$ & $47.93 \pm 0.68$ & $15.95 \pm 0.07$ \\
\hline 3 & $9.04 \pm 0.21$ & $5.60 \pm 0.70$ & $22.4 \pm 1.5$ & $746.8 \pm 16.2$ & $1.16 \pm 0.14$ & $4.00 \pm 0.68$ & $0.019 \pm 0.008$ & $47.52 \pm 0.71$ & $14.89 \pm 1.30$ \\
\hline 4 & $8.84 \pm 0.19$ & $5.42 \pm 0.20$ & $22.0 \pm 0.7$ & $674.5 \pm 19.8$ & $0.96 \pm 0.08$ & $0.54 \pm 0.18$ & $0.018 \pm 0.011$ & $43.63 \pm 1.94$ & $15.97 \pm 1.08$ \\
\hline 5 & $8.90 \pm 0.13$ & $5.45 \pm 0.39$ & $23.7 \pm 1.0$ & $681.0 \pm 57.9$ & $0.50 \pm 0.32$ & $0.18 \pm 0.17$ & $0.006 \pm 0.002$ & $33.17 \pm 2.66$ & $14.99 \pm 0.64$ \\
\hline 6 & $9.18 \pm 0.26$ & $5.42 \pm 0.99$ & $23.5 \pm 1.2$ & $966.3 \pm 11.0$ & $0.73 \pm 0.25$ & $1.00 \pm 0.27$ & $0.016 \pm 0.021$ & $47.97 \pm 0.57$ & $15.33 \pm 0.22$ \\
\hline 7 & $9.20 \pm 0.09$ & $5.82 \pm 0.01$ & $23.1 \pm 1.1$ & $907.5 \pm 7.8$ & $1.50 \pm 0.49$ & $0.19 \pm 0.25$ & $0.022 \pm 0.001$ & $38.80 \pm 0.14$ & $14.78 \pm 0.06$ \\
\hline 8 & $9.56 \pm 0.07$ & $6.06 \pm 0.07$ & $22.7 \pm 0.6$ & $762.5 \pm 26.2$ & $0.95 \pm 0.17$ & $0.00 \pm 0.00$ & $0.015 \pm 0.008$ & $39.42 \pm 0.94$ & $13.35 \pm 1.88$ \\
\hline 9 & $9.10 \pm 0.04$ & $5.82 \pm 0.08$ & $23.2 \pm 0.0$ & $962.0 \pm 8.5$ & $1.60 \pm 0.51$ & $3.28 \pm 0.06$ & $0.036 \pm 0.005$ & $41.60 \pm 3.11$ & $15.26 \pm 1.05$ \\
\hline 10 & $9.84 \pm 0.22$ & $5.32 \pm 0.33$ & $22.5 \pm 1.2$ & $1,108.0 \pm 72.4$ & $1.15 \pm 0.24$ & $2.71 \pm 0.50$ & $0.050 \pm 0.024$ & $52.13 \pm 1.22$ & $13.88 \pm 1.75$ \\
\hline 11 & $9.07 \pm 0.66$ & $5.49 \pm 0.54$ & $22.1 \pm 3.9$ & $1,265.8 \pm 44.3$ & $1.26 \pm 0.22$ & $0.42 \pm 0.35$ & $0.005 \pm 0.001$ & $55.48 \pm 1.63$ & $14.87 \pm 0.38$ \\
\hline 12 & $9.11 \pm 0.39$ & $5.84 \pm 0.35$ & $22.4 \pm 2.3$ & $1,320.8 \pm 28.2$ & $1.23 \pm 0.13$ & $0.14 \pm 0.10$ & $0.006 \pm 0.001$ & $49.23 \pm 5.22$ & $14.47 \pm 0.29$ \\
\hline
\end{tabular}


(A)

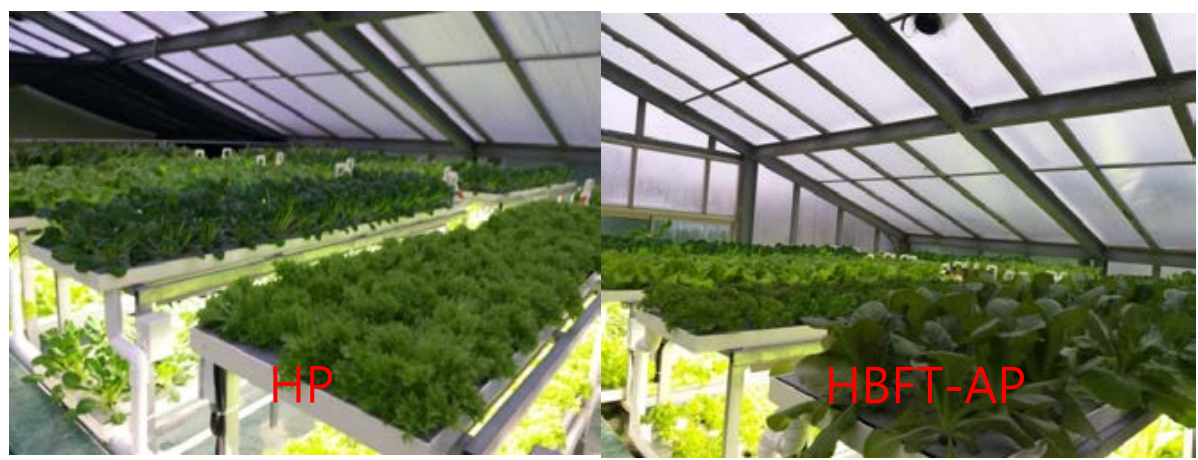

(B)

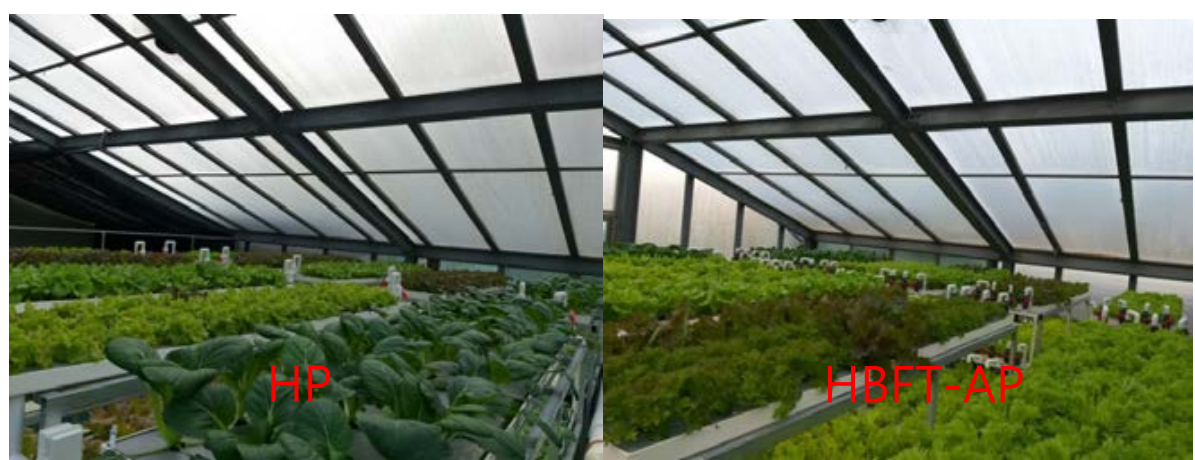

(C)

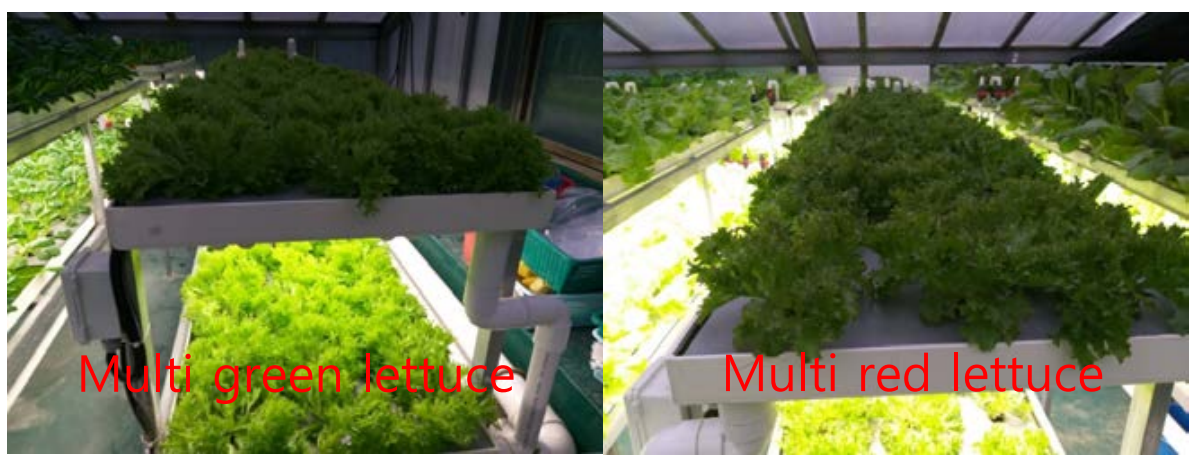

Fig. 3. Growth of leafy vegetables in HP and HBFT-AP for 12 weeks. (A) Exp1, (B) Exp2, (C) multi green and multi red lettuce cultivar. HP, hydroponics; HBFT-AP, hybrid biofloc technology-aquaponics.

\section{Analysis of important nutrients in HBFT-AP and HP culture water}

The results of trace elements [K (mg/L), Ca $(\mathrm{mg} / \mathrm{L}), \mathrm{Mg}(\mathrm{mg} /$ $\mathrm{L}), \mathrm{Na}(\mathrm{mg} / \mathrm{L}), \mathrm{Cl}(\mathrm{mg} / \mathrm{L}), \mathrm{SO}_{4}(\mathrm{mg} / \mathrm{L}), \mathrm{Fe}(\mathrm{mg} / \mathrm{L}), \mathrm{Zn}(\mathrm{mg} / \mathrm{L})$, $\mathrm{Mn}(\mathrm{mg} / \mathrm{L})$ and $\mathrm{Cu}(\mathrm{mg} / \mathrm{L})]$ in HBFT-AP and HP culture water were shown in Table 8 . During the 12-week experimental period, all nutrients except $\mathrm{Cl}$ ions were higher in $\mathrm{HP}$ than in HBFT-AP. Among the nutrients in HBFT-AP culture water analyzed in the last week of Exp1 (Mash) and Exp2 (EP), six nutrients $\left(\mathrm{K}, \mathrm{Ca}, \mathrm{Mg}, \mathrm{Na}, \mathrm{Cl}\right.$, and $\mathrm{SO}_{4}$ ) were lower in $\operatorname{Exp} 1$ than in $\operatorname{Exp} 2$.
Fish growth through two experimental diets (Mash and EP) Compared to fish fed Mash (Exp1), fish fed EP (Exp2) exhibited improvement in weight gain (WG; $11.20 \%$ vs $16.93 \%$ ), feed efficiency (FE; $30.45 \%$ vs $42.91 \%$ ), specific growth rate (SGR; $0.25 \%$ vs $0.37 \%$ ) and protein efficiency ratio (PER; 0.55 vs 0.86 ), although daily feed intake (\%/av.wt/d) and survival rate (\%) were similar (Table 9).

\section{Fish blood analysis}

Hematological characteristics of Japanese eel fed two different diets (Mash and EP) are given in Table 10. In whole blood 
Table 6. Growth of five leafy vegetables in HBFT-AP and HP for 23 days (Exp1)

\begin{tabular}{|c|c|c|c|c|}
\hline \multirow[t]{2}{*}{ Cultivar $(n=12)$} & \multirow[t]{2}{*}{ Growth factor } & \multirow[t]{2}{*}{ Initial } & \multicolumn{2}{|l|}{ Culture method } \\
\hline & & & HBFT-AP & HP \\
\hline \multirow{5}{*}{$\begin{array}{l}\text { Multi green } \\
\text { (Lactuca sativa) }\end{array}$} & Stem mean weight (g) & - & 0.78 & 0.99 \\
\hline & Leaf no. & - & - & - \\
\hline & Leaf weight (g) & $1.49 \pm 0.32$ & $56.15 \pm 11.76^{\mathrm{ns}}$ & $74.83 \pm 12.01$ \\
\hline & Root mean weight (g) & 0.23 & 3.98 & 5.20 \\
\hline & Leaf length $(\mathrm{cm})$ & $3.27 \pm 0.14$ & $14.64 \pm 0.73^{\text {ns }}$ & $15.98 \pm 1.39$ \\
\hline \multirow{5}{*}{$\begin{array}{l}\text { Multi red } \\
\text { (Lactuca sativa) }\end{array}$} & Stem mean weight $(\mathrm{g})$ & - & 0.69 & 0.76 \\
\hline & Leaf no. & - & - & - \\
\hline & Leaf weight (g) & $1.54 \pm 0.26$ & $53.93 \pm 7.56^{\mathrm{ns}}$ & $45.05 \pm 6.18$ \\
\hline & Root mean weight (g) & 0.37 & 2.70 & 2.76 \\
\hline & Leaf length $(\mathrm{cm})$ & $3.84 \pm 0.41$ & $15.23 \pm 0.61^{\text {ns }}$ & $14.48 \pm 0.71$ \\
\hline \multirow{5}{*}{$\begin{array}{l}\text { Swiss chard } \\
\text { (Beta vulgaris) }\end{array}$} & Stem mean weight $(\mathrm{g})$ & - & 0.88 & 0.78 \\
\hline & Leaf no. & $4.25 \pm 0.35$ & $29.12 \pm 3.38^{*}$ & $23.05 \pm 3.05$ \\
\hline & Leaf weight (g) & $2.58 \pm 0.46$ & $92.70 \pm 14.94^{\mathrm{ns}}$ & $81.43 \pm 13.66$ \\
\hline & Root mean weight (g) & 0.28 & 2.48 & 3.98 \\
\hline & Leaf length $(\mathrm{cm})$ & $4.54 \pm 0.26$ & $26.75 \pm 2.30^{\text {ns }}$ & $23.54 \pm 2.46$ \\
\hline \multirow{5}{*}{$\begin{array}{l}\text { Abata lettuce } \\
\text { (Lactuca sativa) }\end{array}$} & Stem mean weight $(\mathrm{g})$ & - & 1.44 & 1.72 \\
\hline & Leaf no. & $6.85 \pm 0.41$ & $20.50 \pm 1.78^{\mathrm{ns}}$ & $18.33 \pm 1.30$ \\
\hline & Leaf weight (g) & $2.72 \pm 0.18$ & $76.90 \pm 8.88^{\mathrm{ns}}$ & $77.79 \pm 8.72$ \\
\hline & Root mean weight (g) & 0.41 & 3.67 & 5.84 \\
\hline & Leaf length $(\mathrm{cm})$ & $6.84 \pm 0.51$ & $22.43 \pm 1.48^{\text {ns }}$ & $24.17 \pm 0.71$ \\
\hline \multirow{5}{*}{$\begin{array}{l}\text { Red romaine lettuce } \\
\text { (Lactuca sativa) }\end{array}$} & Stem mean weight $(\mathrm{g})$ & - & 1.63 & 0.88 \\
\hline & Leaf no. & $5.24 \pm 0.32$ & $21.33 \pm 1.67^{\text {ns }}$ & $19.08 \pm 1.38$ \\
\hline & Leaf weight (g) & $3.98 \pm 0.27$ & $70.81 \pm 5.00^{\mathrm{ns}}$ & $72.61 \pm 9.40$ \\
\hline & Root mean weight (g) & 0.39 & 5.32 & 2.48 \\
\hline & Leaf length $(\mathrm{cm})$ & $6.72 \pm 0.63$ & $28.97 \pm 0.68^{\mathrm{ns}}$ & $30.08 \pm 0.80$ \\
\hline
\end{tabular}

Values (means \pm SD of sampled leafy vegetables) with * superscripts in the same line are significantly different $(p<0.05)$. HBFT-AP, hybrid biofloc technology-aquaponics; HP, hydroponics; ns, nonsignificant.

analysis, PCV was significantly different $(p<0.05)$ between two groups fed Mash $(33.20 \pm 2.86 \%)$ and EP $(38.60 \pm 2.46 \%)$. However, the difference was not found in $\mathrm{Hb}$ (hemoglobin) values between two groups fed Mash $(11.39 \pm 0.94 \mathrm{~g} / \mathrm{dL})$ and EP $(12.82 \pm 0.55 \mathrm{~g} / \mathrm{dL})$. Blood plasma analysis did not show any significant differences $(p>0.05)$ except for the parameters of $\mathrm{Pi}(\mathrm{mg} / \mathrm{dL})$ and $\mathrm{K}(\mathrm{mEq} / \mathrm{L})$ between two groups: GOT $(\mathrm{U} / \mathrm{L})$, $62.00 \pm 18.47$ vs $63.50 \pm 8.46$; GPT (U/L), $5.00 \pm 2.27$ vs $7.20 \pm$ 1.14, GLU (mg/dL), $84.90 \pm 11.58$ vs $67.60 \pm 12.08, \mathrm{Pi}(\mathrm{mg} / \mathrm{dL})$, $5.50 \pm 0.90$ vs $7.04 \pm 0.21, \mathrm{Na}(\mathrm{mEq} / \mathrm{L}), 149.70 \pm 4.27$ vs 148.20 $\pm 2.86, \mathrm{~K}(\mathrm{mEq} / \mathrm{L}), 1.95 \pm 0.44$ vs $2.80 \pm 0.47$, and $\mathrm{Cl}(\mathrm{mEq} / \mathrm{L})$, $145.10 \pm 4.82$ vs $148.40 \pm 2.67$.

\section{Discussion}

The HBFT-AP proposed by Lee et al. (2019a, 2019b) was applied in this study. After a successful attempt of the HBFT-AP at the semi-pilot scale (Lee et al. 2019b), Lee et al. (2019a) reported the higher productivity of leafy vegetables in the system using catfish than in a circulating hydroponics from field test.

Although Bittsanszky et al. (2016) reported that nutrient levels change depending on the density of fish, but nitrates are sufficiently generated in the aquaponic system, it is commonly accepted that $\mathrm{P}, \mathrm{Ca}, \mathrm{Fe}$, and $\mathrm{K}$ are largely deficient for optimal growth of plants (Rakocy, 2007). According to Lee \& Lee (2014), after the discovery of Arthrobacter sp. performing the heterotrophic nitrification process in 1972, many studies on the process 
Table 7. Growth of five leafy vegetables in HBFT-AP and HP for 23 days (Exp2)

\begin{tabular}{|c|c|c|c|c|}
\hline \multirow[t]{2}{*}{ Cultivar $(n=12)$} & \multirow[t]{2}{*}{ Growth factor } & \multirow[t]{2}{*}{ Initial } & \multicolumn{2}{|l|}{ Culture method } \\
\hline & & & HBFT-AP & HP \\
\hline \multirow{5}{*}{$\begin{array}{l}\text { Multi green } \\
\text { (Lactuca sativa) }\end{array}$} & Stem mean weight $(\mathrm{g})$ & - & 0.66 & 0.78 \\
\hline & Leaf no. & - & - & - \\
\hline & Leaf weight (g) & $1.39 \pm 0.27$ & $58.61 \pm 9.51^{\text {ns }}$ & $47.76 \pm 13.67$ \\
\hline & Root mean weight (g) & 0.18 & 5.42 & 5.54 \\
\hline & Leaf length $(\mathrm{cm})$ & $3.08 \pm 0.09$ & $16.30 \pm 1.08^{\text {ns }}$ & $13.87 \pm 1.26$ \\
\hline \multirow{5}{*}{$\begin{array}{l}\text { Red lettuce } \\
\text { (Lactuca sativa) }\end{array}$} & Stem mean weight $(\mathrm{g})$ & - & 1.18 & 0.95 \\
\hline & Leaf no. & $3.86 \pm 0.24$ & $15.33 \pm 1.72^{\text {ns }}$ & $14.67 \pm 1.72$ \\
\hline & Leaf weight (g) & $2.62 \pm 0.18$ & $48.89 \pm 6.26^{\mathrm{ns}}$ & $39.08 \pm 7.41$ \\
\hline & Root mean weight (g) & 0.28 & 4.11 & 3.68 \\
\hline & Leaf length $(\mathrm{cm})$ & $4.72 \pm 0.38$ & $25.39 \pm 2.03^{*}$ & $21.93 \pm 1.23$ \\
\hline \multirow{5}{*}{$\begin{array}{l}\text { Haetsal Jeokchukmyeon } \\
\text { (Lactuca sativa) }\end{array}$} & Stem mean weight $(\mathrm{g})$ & - & 1.36 & 1.25 \\
\hline & Leaf no. & $5.34 \pm 0.68$ & $10.58 \pm 2.31^{\mathrm{ns}}$ & $9.33 \pm 0.65$ \\
\hline & Leaf weight (g) & $3.02 \pm 0.25$ & $56.98 \pm 16.60^{\mathrm{ns}}$ & $43.31 \pm 9.07$ \\
\hline & Root mean weight (g) & 0.18 & 4.51 & 4.40 \\
\hline & Leaf length $(\mathrm{cm})$ & $6.42 \pm 0.58$ & $19.08 \pm 1.67^{*}$ & $15.33 \pm 0.85$ \\
\hline \multirow{5}{*}{$\begin{array}{l}\text { Abata lettuce } \\
\text { (Lactuca sativa) }\end{array}$} & Stem mean weight (g) & - & 1.62 & 1.36 \\
\hline & Leaf no. & $6.12 \pm 0.28$ & $14.42 \pm 0.79^{\mathrm{ns}}$ & $13.75 \pm 1.36$ \\
\hline & Leaf weight (g) & $2.05 \pm 0.26$ & $89.67 \pm 11.33^{*}$ & $63.61 \pm 13.15$ \\
\hline & Root mean weight (g) & 0.29 & 4.20 & 7.27 \\
\hline & Leaf length $(\mathrm{cm})$ & $5.42 \pm 0.24$ & $21.69 \pm 1.07^{\mathrm{ns}}$ & $19.04 \pm 1.56$ \\
\hline \multirow{5}{*}{$\begin{array}{l}\text { Da cheong chae } \\
\text { (Brassica campestris) }\end{array}$} & Stem mean weight $(\mathrm{g})$ & - & 1.10 & 1.08 \\
\hline & Leaf no. & $3.89 \pm 0.42$ & $10.67 \pm 1.72^{\mathrm{ns}}$ & $10.33 \pm 1.50$ \\
\hline & Leaf weight (g) & $3.12 \pm 0.22$ & $73.92 \pm 17.55^{\mathrm{ns}}$ & $65.24 \pm 26.29$ \\
\hline & Root mean weight (g) & 0.16 & 3.14 & 4.86 \\
\hline & Leaf length $(\mathrm{cm})$ & $5.24 \pm 0.38$ & $28.84 \pm 1.79^{\mathrm{ns}}$ & $27.62 \pm 2.33$ \\
\hline
\end{tabular}

Values (means \pm SD of sampled leafy vegetables) with * superscripts in the same line are significantly different $(p<0.05)$

HBFT-AP, hybrid biofloc technology-aquaponics; HP, hydroponics; ns, nonsignificant.

have been conducted. Researchers have discovered a variety of heterotrophic nitrifying microorganisms with nitrification activity in soil, sludge, lake water, and the deep sea (Spiller et al., 1976). In the heterotrophic nitrification and aerobic denitrification processes, two reactions can occur in one reactor at the same time. As well, the change in $\mathrm{pH}$ in the reactor is kept in a balanced manner during the denitrification process, thereby inhibiting the acidification process occurring in the nitrification process. Since the end products and substrates of heterotrophic nitrification are diverse, there is an advantage that the range of application and mixed culture of various types of microorganisms can be broadly expanded (Marazioti et al., 2003). The heterotrophic nitrification process of $T$. pantotropha requires energy and unlike autotrophic nitrifying bacteria, the bacteria does not accumulate $\mathrm{NO}_{2}-\mathrm{N}$ when ammonia is oxidized under aerobic conditions (Robertson et al., 1988). In addition, Kim et al. (2005) reported that Bacillus strains predominantly inhabit the systems that treat contaminated water, and effectively remove organic matter other than nitrogen and phosphorus. Currently, researches on BFT method using heterotrophic bacteria to the aquaponic production system are being attempted (Emerenciano et al., 2017), but many microorganisms formed during the process attach to the plant roots to form a biofilm, which has been pointed out as a major factor that inhibits the growth of plants. It is known that a filter and a solids settling device are essential to compensate for the issue (Emerenciano et al., 2017). In Exp1 and Exp2, the BFT method reported by Emerenciano et al. (2017) was applied during the initial one week with a 
Table 8. Nutrient concentrations in HBFT-AP and HP at the end of the trial

\begin{tabular}{llll}
\hline $\begin{array}{l}\text { Water quality parameter } \\
\text { (mg/L) }\end{array}$ & \multicolumn{2}{l}{ HBFT-AP } \\
\cline { 2 - 3 } & Mash (1-6 wk) & EP (7-12 wk) \\
\hline $\mathrm{K}$ & 2.9 & 9.6 & 52.0 \\
$\mathrm{Ca}$ & 45.6 & 67.4 & 147.8 \\
$\mathrm{Mg}$ & 5.0 & 6.5 & 33.6 \\
$\mathrm{Na}$ & 13.6 & 16.8 & 33.4 \\
$\mathrm{Cl}$ & 12.0 & 17.0 & 10.0 \\
$\mathrm{SO}_{4}$ & 20.0 & 27.0 & 84.0 \\
$\mathrm{Fe}$ & 0.0743 & 0.0610 & 2.0090 \\
$\mathrm{Zn}$ & 0.6900 & 0.3320 & 0.6917 \\
$\mathrm{Mn}$ & 0.0090 & 0.0010 & 0.1021 \\
$\mathrm{Cu}$ & 0.0170 & 0.0130 & 0.9066 \\
\hline
\end{tabular}

Values are means of 2 determinations.

HBFT-AP, hybrid biofloc technology-aquaponics; HP, hydroponics; Mash, commercial powdered feed; EP, extruded pellet.

Table 9. Growth performance of Japanese eel in HBFT-AP for 12 weeks ${ }^{11}$

\begin{tabular}{|c|c|c|}
\hline \multirow[t]{2}{*}{ Growth performance } & \multicolumn{2}{|l|}{ Diet } \\
\hline & Mash (1-6 wk) & $\mathrm{EP}(7-12 w k)$ \\
\hline Initial fish No. & 367 & 361 \\
\hline Final fish No. & 361 & 357 \\
\hline Initial weight of total fish (g) & 82,130 & 91,320 \\
\hline Final weight of total fish (g) & 91,320 & 106,780 \\
\hline Initial average $(n=50)$ weight of total fish (g) & $225.5 \pm 20.7$ & $249.7 \pm 21.6$ \\
\hline Final average $(n=50)$ weight of total fish $(g)$ & $249.7 \pm 21.6$ & $296.9 \pm 24.3$ \\
\hline Feed intake(g, DM) & 30,199 & 36,026 \\
\hline WG $(\%)^{2)}$ & 11.20 & 16.93 \\
\hline $\mathrm{FE}(\%)^{3)}$ & 30.45 & 42.91 \\
\hline $\operatorname{SGR}(\%)^{4)}$ & 0.25 & 0.37 \\
\hline $\mathrm{PER}^{5)}$ & 0.55 & 0.86 \\
\hline $\mathrm{DF}^{6)}$ & 0.57 & 0.58 \\
\hline Survival rate $(\%)^{7)}$ & 98.2 & 98.9 \\
\hline 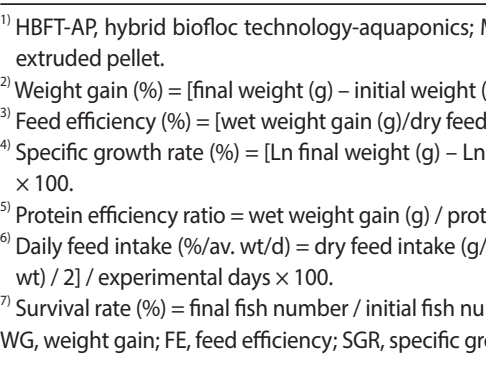 & $\begin{array}{l}\text { ash, commercial p } \\
\text { l)] } \times 100 / \text { initial weic } \\
\text { ntake] } \times 100 \text {. } \\
\text { nitial weight (g)] } / \epsilon \\
\text { in intake. } \\
\text { sh) } /[\text { [initial wt + fi } \\
\text { hber } \times 100 \text {. }\end{array}$ & $\begin{array}{l}\text { owdered feed; EP, } \\
\text { ght (g). } \\
\text { experimental days } \\
\text { inal wt + dead fish }\end{array}$ \\
\hline
\end{tabular}

Table 10. Hematological analysis of Japanese eel in HBFTAP $^{11}$

\begin{tabular}{lll}
\hline \multirow{2}{*}{ Blood parameters } & \multicolumn{2}{l}{ Diet } \\
\cline { 2 - 3 } & \multicolumn{1}{l}{ Mash $(1-6 \mathrm{wk})$} & EP $(7-12 \mathrm{wk})$ \\
\hline Average fish weight $(\mathrm{n}=4)$ & $232.20 \pm 38.96^{\mathrm{ns}}$ & $299.80 \pm 18.05$ \\
$\mathrm{PCV}(\%)$ & $33.20 \pm 2.86^{*}$ & $38.60 \pm 2.46$ \\
$\mathrm{Hb}(\mathrm{g} / \mathrm{dL})$ & $11.39 \pm 0.94^{\mathrm{ns}}$ & $12.82 \pm 0.55$ \\
$\mathrm{GOT}(\mathrm{U} / \mathrm{L})$ & $62.00 \pm 18.47^{\mathrm{ns}}$ & $63.50 \pm 8.46$ \\
$\mathrm{GPT}(\mathrm{U} / \mathrm{L})$ & $5.00 \pm 2.27^{\mathrm{ns}^{\mathrm{s}}}$ & $7.20 \pm 1.14$ \\
$\mathrm{GLU}(\mathrm{mg} / \mathrm{dL})$ & $84.90 \pm 11.58^{\mathrm{ns}}$ & $67.60 \pm 12.08$ \\
$\mathrm{Pi}(\mathrm{mg} / \mathrm{dL})$ & $5.50 \pm 0.90^{*}$ & $7.04 \pm 0.21$ \\
$\mathrm{Na}(\mathrm{mEq} / \mathrm{L})$ & $149.70 \pm 4.27^{\mathrm{ns}}$ & $148.20 \pm 2.86$ \\
$\mathrm{~K}(\mathrm{mEq} / \mathrm{L})$ & $1.95 \pm 0.44^{*}$ & $2.80 \pm 0.47$ \\
$\mathrm{Cl}(\mathrm{mEq} / \mathrm{L})$ & $145.10 \pm 4.82^{\mathrm{ns}}$ & $148.40 \pm 2.67$
\end{tabular}

${ }^{11}$ Values (means \pm SD of four individuals) with *superscripts in the same line are significantly different $(p<0.05)$.

HBFT-AP, hybrid biofloc technology-aquaponics; Mash, commercial powdered feed; $\mathrm{EP}_{\imath}$ extruded pellet; $\mathrm{ns}$, nonsignificant; $\mathrm{PCV}$, hematocrit; $\mathrm{Hb}$, hemoglobin; $\mathrm{GOT}$, glutamic oxaloacetic transaminase; GPT, glutamic pyruvic transaminase; GLU, glucose; Pi, inorganic phosphorus; Mash, commercial powdered feed; CP, crude protein.

supply of refined glucose as the organic carbon. The daily total ammonia (TAN), nitrite $\left(\mathrm{NO}_{2}-\mathrm{N}\right)$ and nitrate $\left(\mathrm{NO}_{3}-\mathrm{N}\right)$ levels were changed with the amount of organic carbon supplied in HBFT-AP culture water. On the other hand, the level of phosphorus $\left(\mathrm{PO}_{4}-\mathrm{P}\right)$ was similar or lower than that of the initial water (Table 4). In addition, the turbidity was highest due to the proliferation of heterotrophic bacteria, while the $\mathrm{pH}$ remained stable during this period. Following the supply of organic carbon for the $1^{\text {st }}$ week, the carbon source was switched to $\mathrm{CO}_{2}$ (inorganic carbon) to increase the activity of the nitrification process of autotrophic bacteria and the carbonic acid concentration in the system. The $\mathrm{pH}$ in the system was, then, started to decrease (Table 4). Kim et al. (2005) reported that autotrophic bacteria exert the nitrification stronger than heterotrophic ones and that they are, however, less active at $\mathrm{pH} 6.0$ or less, making it difficult to convert ammonia into nitrite during the process. As a result, nitrate levels no longer increased as indicated by Thorarinsdottir (2015). Differently from those findings, the present study showed the increase of TAN and $\mathrm{NO}_{3}-\mathrm{N}$ and the stabilization of $\mathrm{NO}_{2}-\mathrm{N}$ (Table 4). Such a result could be due to the nitrification process performed by three species of heterotrophic bacteria like Bacillus (Bacillus subtilis, B. amuloliquefaciens, $B$. licheniformis). In water, non-ionized ammonia $\left(\mathrm{NH}_{3}\right)$ and ammonium $\left(\mathrm{NH}_{4}^{+}\right)$equilibrate with $\mathrm{pH}$ and temperature, and the sum of the two forms is called TAN (Purwono et al., 
2017). Both $\mathrm{NH}_{3}$ and $\mathrm{NH}_{4}{ }^{+}$can be toxic to fish, but the former is a more toxic form because it is not charged and is fat-soluble, so it passes through biomembrane more easily than the ionized and charged $\mathrm{NH}_{4}{ }^{+}$. In most cases, ammonia nitrogen is recognized to be toxic for farmed fish at concentrations above 1.5 $\mathrm{mg} / \mathrm{L}$, but the toxicity threshold level of $\mathrm{NH}_{3}$ is only $0.025 \mathrm{mg} /$ L. It can vary greatly depending on species, fish size, fine solids, refractory organics, surface active compounds, metals, nitrate, salinity and $\mathrm{pH}$ (Avnimelech et al., 2015). Japanese eel was able to survive and grow under high TAN concentrations $(4.15 \mathrm{mg} / \mathrm{L})$ in the last week of 12 weeks of this experiment. The reason is assumed that most TAN was converted to $\mathrm{NH}_{4}{ }^{+}$form rather than $\mathrm{NH}_{3}$ at low $\mathrm{pH}$ (Purwono et al., 2017), therefore the toxicity of TAN was suppressed.

Protein in fish feed is the most expensive component of energy and essential nutrient for growth. For this reason, the protein requirement is the first to be considered in the formulation of fish feeds (Han et al., 2005). In the case of fish fed a diet that lacks energy compared to protein, feed protein is used as an energy source to meet the energy required for maintenance in the fish body. As a result, PER and growth factor decrease as well as leading to excessive nitrogen excretion (Cai et al., 1996; McGoogan \& Gatlin, 1999). Fish fed a diet that contains an excess of energy compared to protein component consume less feed and cannot receive enough other essential nutrients such as protein and amino acids. Eventually, it results in poor growth (McGoogan \& Gatlin, 1999). The appropriate protein level in diet for Japanese eel is known to be about $45 \%-50 \%$, but it can vary depending on fish species, feed composition, experimental design, breeding method and environmental factors such as water temperature and salinity (Degani et al., 1985; De Silva et al., 2008; Keembiyehetty \& Wilson, 1998; Nose \& Arai, 1973; Tibbetts et al., 2000). Currently, commercial feed for Japanese eel in Korea is a powdered type in which fish meal and gelatinized starch are mixed, and is provided to the fish in a dough form after mixing it with water. Kim et al. (2008) reported that the powdered type feed was less effective than the extruded pellet in spite of the similar protein content because a significant loss of feed could be caused during feeding the dough. In this study, the growth factors (WG, FE, SGR, and PER) of Japanese eel were higher in feeding period of the EP than the Mash (Table 9). The reason might be due to a difference in the actual feed consumption, although the feeding amounts of the two diets were similar at the rate of $0.57 \%$ and $0.58 \%$ (Table 5). In hematological index measured at the end $\left(6^{\text {th }}\right.$ and $12^{\text {th }}$ week) of feeding of Mash and EP, respectively, the parameters of PCV, in- organic phosphorus and potassium ion (K) showed a significant difference (Table 10). Jeon et al. (2003) reported that the values of $\mathrm{PCV}(\%)$ and $\mathrm{Hb}(\mathrm{g} / \mathrm{dL})$ ranged from $31.8 \%$ to $42.5 \%$ and from 11.1 to $14.0 \mathrm{~g} / \mathrm{dL}$ for Japanese eel, and were changed according to the size and sex of the fish. Lee et al. (2020) reported that the mean values ranged from $31.25 \%$ to $38.50 \%$ for PCV (\%) and from 11.40 to $12.98 \mathrm{~g} / \mathrm{dL} \mathrm{Hb}(\mathrm{g} / \mathrm{dL})$ in the hematological analysis of Japanese eel with body weight of $220 \mathrm{~g}$ grown in HBFT-AP system. It was also found that the concentration of $\mathrm{Pi}(\mathrm{mg} / \mathrm{dL})$ and $\mathrm{K}(\mathrm{mEq} / \mathrm{L})$ in blood plasma was higher in fish group fed diet containing MKP. Lee et al. (2019a, b) reported that the values of PCV (\%) and $\mathrm{Hb}(\mathrm{g} / \mathrm{dL})$ ranged from $45.33 \%$ to $47.83 \%$ and from 14.03 to $15.48 \mathrm{~g} / \mathrm{dL}$ in Far Eastern catfish weighing 200-300 g grown in HBFT-AP system. PCV and $\mathrm{Hb}$ are main indicators of the ability to carry oxygen from blood to each tissue and nutritional anemia in fish. In this study, Japanese eel fed EP showed higher PCV values in the whole blood analysis (Table 10). This could be explained by reinforced oxygen transport capacity required for the metabolic processes of the fish kept in low $\mathrm{pH}$ condition in a closed environment, and it might be considered to be the result of the adaptation to the hazardous environment. Lee et al. (2019b) reported that the concentration of $\mathrm{Pi}(\mathrm{mg} / \mathrm{dL})$ and $\mathrm{K}$ $(\mathrm{mEq} / \mathrm{L})$ in blood plasma of Far Eastern catfish fed diets containing more than MKP 2.0\% was similar. Also, plasma Pi (mg/dL) of Japanese eel fed EP with MKP 2.7\% was higher than that of fish fed commercial EP without MKP. In this study, similarly, higher values of $\mathrm{Pi}(\mathrm{m} / \mathrm{dL})$ and $\mathrm{K}(\mathrm{mEq} / \mathrm{L})$ were observed in Japanese eel fed EP with MKP 2.7\%. These results suggest that dietary MKP increase the plasma $\mathrm{Pi}(\mathrm{m} / \mathrm{dL})$ and $\mathrm{K}(\mathrm{mEq} / \mathrm{L})$ of fish.

Hydroponics is divided into two cultures 'water and medium' depending on whether or not the medium is used, and into two systems 'open and closed' depending on whether or not the culture nutrition solution is reused. In water culture, plants grow with nutrition solution without solid medium supporting the roots of plants. This cultivation method includes deep water culture (DWC), nutrient film technique (NFT), aeroponics, and capillary culture. The HP production system used in the present study was a DWC method, but the height of the plant bed was about 10 to $15 \mathrm{~cm}$, which was lower than that of the bed being conventionally used (Fig. 1). Jang et al. (2017) reported that closed system can minimize environmental pollution by reducing the discharge of nutrients such as nitrogen and phosphorus through reuse of waste nutrient solution, and also improve economic efficiency by sparing the amount of fertilizer and raw water used in the system. Despite these ad- 
vantages, however, several researchers reported that when the cultivation period is prolonged in closed system, the imbalance of ions in the culture medium becomes serious as the circulation progresses, which negatively affects the growth and yield of crops (Ho \& Adams, 1995; Lopez et al., 1996; Zekki et al., 1996). Contrary to those findings, Dhakal et al. (2005) reported that there was no difference in the yield between open and closed systems when cultivating tomatoes using a medium containing $28 \%$ organic matter. Based on these contradictory results, it is inferred that the concentration of nutrients absorbed by plants varies depending on drainage components, environmental conditions and growing stages, and that plants maintain their own favorable growth and development by ion selectivity (Abram, 1980). In present study, 8 kinds of leafy vegetables were stocked and cultivated twice (Exp1, $3^{\text {rd }}$ to $6^{\text {th }}$ weeks; Exp2, $9^{\text {th }}$ to $12^{\text {th }}$ weeks) in two systems HBFT-AP and HP, respectively. During the two experimental periods, productivity of leafy vegetables showed a similar (4 kinds of cultivar) or somewhat higher trend (4 kinds of species) in HBFT-AP than in HP (Table 6 and 7). Such a difference between two systems is assumed to be due to the influence of the $\mathrm{pH}$. The value in HP was frequently kept lower than 5.0 in both Exp1 and Exp2, while the value in HBFT maintained at the range around 5.5 for the entire experimental period. In an aquaponic system in which aquatic organisms and plants are cultured and grown together, it is important to maintain the water quality environment of both sides in the appropriate range within the biological limits (FAO, 2014). In general, the $\mathrm{pH}$ value of culture water for hydroponics is good from 5.5 to 6.5 , and when the value falls below 4.5 , alkaline nutrients such as $\mathrm{Ca}, \mathrm{Mg}$, and $\mathrm{K}$ are insoluble. On the contrary, when the $\mathrm{pH}$ is 7 or higher, ferric iron $\left(\mathrm{Fe}^{3+}\right)$ precipitates and becomes unavailable by plants (Moore, 1974; Islam et al., 1980). In addition, it was reported that the symptom of yellowing leaves symptoms is related to the absorption, transport and function of inorganic ions, and poor development frequently occurs under conditions of inappropriate $\mathrm{pH}$ (Findenegg et al., 1986). In the case of fish, it is known that they do not survive below $\mathrm{pH}$ 4.0 , and do not grow in the range of $\mathrm{pH} 4.0$ to 5.0, so there is no productivity, while at $\mathrm{pH} 9.0$ to 11.0 , growth is slow, and at $\mathrm{pH}$ 11 or higher, dead individuals appear (Thorarinsdottir, 2015). Lee et al. $(2019 \mathrm{a}, \mathrm{b})$ reported that a $\mathrm{pH}$ range of 5.0 to 6.0 could produce both Far Eastern catfish and leafy vegetables without any problems in HBFT-AP system. Based on the previous and present results, therefore, it could be highlighted that the range of $\mathrm{pH} 5.5$ to 6.0 is an adequate condition for both productivity and survival of both fish and leafy vegetables in the HBFT-AP.

During trials of Exp1 and Exp2, nutrient concentrations except for $\mathrm{Cl}$ ions were higher in HP than in HBFT-AP (Table 8). Nevertheless, productivity of leafy vegetables was similar or even lower in HP. This could be explained by the amount of culture water of HBFT-AP, which is much larger than that of HP (HBFT-AP, 16 tons vs HP, 4 tons). Therefore, the quantitative concentration of nutrients did not cause a problem in the growth of leafy vegetables in aquaponics (FAO, 2014). Higher level of calcium ion in both systems was due to the addition of water soaked out of oyster shells to prevent a drop of the $\mathrm{pH}$ below 5.0 (Table 8). In growth trial of leaf vegetables in HBFT-AP, higher concentration of potassium ion in culture water during EP feeding period would be originated from fecal dissolution of the ion, because the feed contained MKP of $2.7 \%$.

\section{Conclusion}

We investigated that how the commercial powdered diet and an extruded pellet containing MKP affect the productivity of leafy vegetables in the HBFT-AP using Japanese eel. Also, the feasibility of the practical application of HBFT-AP was examined by comparing with HP in terms of the productivity of leafy vegetables. The characteristics of the nitrification process in HBFT-AP for this study were shown as an increase of TAN and $\mathrm{NO}_{3}-\mathrm{N}$ and a stabilization of $\mathrm{NO}_{2}-\mathrm{N}$. It is presumed that such a trend could be achieved by heterotrophic bacteria. Japanese eel fed EP showed higher PCV values in the whole blood analysis and higher values of $\mathrm{Pi}(\mathrm{m} / \mathrm{dL})$ and $\mathrm{K}(\mathrm{mEq} / \mathrm{L})$ were observed in plasma. This could be explained by reinforced oxygen transport capacity required for the metabolic processes of the fish kept in low $\mathrm{pH}$ condition in a closed environment. And also, dietary MKP might increase the plasma $\mathrm{Pi}(\mathrm{m} / \mathrm{dL})$ and $\mathrm{K}$ (mEq/ L). Leafy vegetables in HBFT-AP showed a productivity similar (4 kinds of cultivar) or somewhat higher (4 kinds of cultivar) compared to those in HP. It was suggested that $\mathrm{pH}$ in HBFT-AP vary depending on nutrients in the diet, the microorganisms, and $\mathrm{CO}_{2}$ concentration in the culture water, and that if the $\mathrm{pH}$ in HBFT-AP is kept at 5.5 to 6.0, nutrient level in the culture water does not exert any adverse effect on plant growth. The low-pH aquaponic system called HBFT-AP would be emerged as a solution to complement the facility cost and operational complexity problems of the RAS-based aquaponics, although more researches remains to be done. 


\section{Competing interests}

No potential conflict of interest relevant to this article was reported.

\section{Funding sources}

This work was supported by Korea Institute of Planning and Evaluation for Technology in Food, Agriculture, Forestry (IPET) through Agri-Bio industry Technology Development Program, funded by Ministry of Agriculture, Food and Rural Affairs (MAFRA), Korea (grant number: 118049-03-2-HD020).

\section{Acknowledgements}

Not applicable.

\section{Availability of data and materials}

Upon reasonable request, the datasets of this study can be available from the corresponding author.

\section{Ethics approval and consent to participate}

This article does not require IRB/IACUC approval because there are no human and animal participants.

\section{ORCID}

Dong Hoon Lee https://orcid.org/0000-0002-2150-6778 Jeong-Dae Kim https://orcid.org/0000-0001-8761-319X

\section{References}

Abram AS. The selective capacity of plants for ions and its importance for the composition and treatment of the nutrient solution. Acta Hortic. 1980;98:87-98.

Avnimelech Y, De-Schryver P, Emmereciano M, Kuhn D, Ray A, Taw N. Overview of aquaculture systems. In: Tomasso J, editor. Biofloc technology. Baton Rouge, LA: The World Aquaculture Society Press; 2015. p. 9-20.

Bailey DS, Ferrarezi RS. Valuation of vegetable crops produced in the UVI commercial aquaponic system. Aquacult Rep. 2017;7:77-82.

Bittsanszky A, Uzinger N, Gyulai G, Mathis A, Junge R, Villarroel $\mathrm{M}$, et al. Nutrient supply of plants in aquaponic systems. Ecocycles. 2016;2:17-20.

Cai Y, Wermerskirchen J, Adelman IR. Ammonia excretion rate indicates dietary protein adequacy for fish. Prog Fish Cult. 1996;58:124-7.

Cho SH, Jeong JH, Kim MH, Lee KT, Kim DJ, Kim KH, et al.
The effects of temperature on maintaining the stability of water quality in biofloc-based zero-water exchange culture tanks. J Life Sci. 2015;25:496-506.

Degani G, Horowitz A, Levanon D. Effect of protein level in purified diet and of density, ammonia and $\mathrm{O}_{2}$ level on growth of juvenile European eels (Anguilla anguilla L.). Aquaculture. 1985;46:193-200.

De Silva SS, Gunasekera RM, Gooley G, Ingram BA. Growth of Australian shortfin eel (Anguilla australis) elvers given different dietary protein and lipid levels. Aquacult Nutr. 2008;7:53-7.

Dhakal U, Salokhe VM, Tantau HJ, Max J. Development of a greenhouse nutrient recycling system for tomato production in humid tropics. Agric Eng Int CIGR Ejournal. 2005;7:1-15.

Duncan DB. Multiple range and multiple F tests. Biometrics. 1955;11:1-42.

Emerenciano MGC, Martínez-Córdova LR, Martínez-Porchas M, Miranda-Baeza A. Biofoc technology (BFT): a tool for water quality management in aquaculture. In: Tutu $\mathrm{H}$, editor. Water quality. London, UK: IntechOpen; 2017. p. 91109.

FAO [Food and Agriculture Organization of the United Nations]. Flow-through and recirculation systems: Report of the working group on terminology, format and units of measurement. Rome: FAO; 1986. EIFAC Technical Paper No.: 44.

FAO [Food and Agriculture Organization of the United Nations]. Small-scale aquaponic food production: integrated fish and plant farming. Rome: FAO; 2014. FAO Fisheries and Aquaculture Technical Paper No.: 589.

Findenegg GR, van Beusichem ML, Keltjens WG. Proton balance of plants: physiological, agronomical and ecological implications. Neth J Agric Sci. 1986;34:371-9.

Gieling TH, van Straten G, Janssen HJJ, Wouters H. ISE and Chemfet sensors in greenhouse cultivation. Sens Actuators B Chem. 2005;105:74-80.

Gutiérrez M, Alegret S, Cáceres R, Casadesús J, Marfà O, del Valle M. Nutrient solution monitoring in greenhouse cultivation employing a potentiometric electronic tongue. J Agric Food Chem. 2008;56:1810-7.

Han KM, Bae JY, Eme OO, Go SH, Yoo JH, Bai SC. Evaluation of the optimum dietary protein to energy ratio of juvenile Japanese eel, Anguilla japonica. J Aquacult. 2005;18:135141. 
Ho LC, Adams P. Nutrient uptake and distribution in relation to crop quality. Acta Hortic. 1995;396:33-44.

Islam AKMS, Edwards DG, Asher CJ. pH optima for crop growth. Plant Soil. 1980;54:339-57.

Jang D, Choi KY, Kim IS. Effect of drainage reusing ratio on growth and yield of summer-cultivated paprika in recycling hydroponic cultivation. Protected Hortic. 2017;26:7-12.

Jeon MJ, Han KM, Bae JY, Yoo JH, Lee KA, Bai SC. Serum steroid hormone level and hematological characteristics of one-year cultured eels, Anguilla japonica based on total length and sex. J Aquacult. 2003;16:267-72.

Keembiyehetty CN, Wilson RP. Effect of water temperature on growth and nutrient utilization of sunshine bass (Morone chrysops + + $\times$ Morone saxatilis $\hat{\delta}$ ) fed diets containing different energy/protein ratios. Aquaculture. 1998;166:151-62.

Kim JD, Kim KS, Song JS, Lee JY, Jeong KS. Optimum level of dietary monocalcium phosphate based on growth and phosphorus excretion of mirror carp, Cyprinus carpio. Aquaculture. 1998;161:337-44.

Kim JK, Park KJ, Cho KS, Nam SW, Park TJ, Bajpai R. Aerobic nitrification-denitrification by heterotrophic Bacillus strains. Bioresour Technol. 2005;96:1897-906.

Kim SW, Rim SK, Sohn SG, Lee J. Comparison of growth and water quality in juvenile Japanese eel, Anguilla japonica fed commercial extruded pellet and paste type diets. J Fish Mar Sci Edu. 2008;20:90-4.

Kumar RR, Cho JY. Reuse of hydroponic waste solution. Environ Sci Pollut Res Int. 2014;21:9569-77.

Lall SP. Digestibility, metabolism and excretion of dietary phosphorus in fish. In: Proceedings of the 1st International Symposium on Nutritional Strategies in Management of Aquaculture Waste; 1991; Guelph, ON. p. 21-36.

Lee DH, Kim JY, Lim SR, Kim DY, Kim KB, Kim JM, et al. Comparative study on growth and yield of far Eastern catfish Silurus asotus and leafy vegetables grown in hybrid BFT-aquaponics, semi-RAS and hydroponics. Korean J Fish Aquat Sci. 2019a;52:482-95.

Lee DH, Kim JY, Lim SR, Kim DY, Kim JM, Shin SJ, et al. Effect of dietary monobasic potassium phosphate levels on water quality and the growth of far Eastern catfish Silurus asotus and four leafy vegetables in a hybrid biofloc technology aquaponic system. Korean J Fish Aquat Sci. 2019b;52:15972 .

Lee DH, Kim JY, Lim SR, Kim KB, Kim JM, Hariati AM, et al. Effects of crude protein levels in diets containing MKP on water quality and the growth of Japanese eels Anguilla japonica and leafy vegetables in a hybrid BFT-aquaponic system. Korean J Fish Aquat Sci. 2020;53:606-19.

Lee EY, Lee CW. Isolation and nitrogen removal characteristics of heterotrophic nitrification-aerobic denitrifying bacteria, Stenotrophomonas sp. CW-4Y. Korean Soc Biotechnol Bioeng J. 2014;29:72-80.

Lopez J, Tremblay N, Voogt W, Dubé S, Gosselin A. Effects of varying sulphate concentrations on growth, physiology and yield of the greenhouse tomato. Sci Hortic. 1996;67:207-17.

Losordo TM, Westerman PW, Liehr SK. Water treatment and wastewater generation in intensive recirculating fish production systems. Bull Natl Res Inst Aquacult Suppl. 1994;1:27-36.

Marazioti C, Kornaros M, Lyberatos G. Kinetic modeling of a mixed culture of Pseudomonas denitrificans and Bacillus subtilis under aerobic and anoxic operating conditions. Water Res. 2003;37:1239-51.

McGoogan BB, Gatlin DM. Dietary manipulations affecting growth and nitrogenous waste production of red drum, Sciaenops ocellatus I. effects of dietary protein and energy levels. Aquaculture. 1999;178:333-48.

MOF [Ministry of Oceans and Fisheries]. Fisheries statistics [Internet]. 2019 [cited 2020 Aug 11]. https://www.fips. go.kr/p/S020304/\#

Moore DP. Physiological effects of $\mathrm{pH}$ on roots. In: Carson EW, editor. The plant root and its environment. Charlottesville, VA: University Press of Virginia; 1974. p. 135-51.

NIFS [National Institute of Fisheries Science]. 2012 FAO world fisheries trends. Busan, Korea: Hanguel Graphic; 2013. p. 194-205.

Nose T, Arai S. Optimum level of protein in purified diet for eel, Anguilla japonica. Bull Freshwater Fish Res Lab. 1973;22:145-55.

Ogino J, Takeuchi L Takeda H, Watanabe T. Availability of dietary phosphorus in carp and rainbow trout. Bull Jpn Soc Sci Fish. 1979;45:1527-32.

Purwono AR, Hibbaan M, Budihardjo MA. Ammonia-nitrogen $\left(\mathrm{NH}_{3}-\mathrm{N}\right)$ and ammonium-nitrogen $\left(\mathrm{NH}_{4}{ }^{+}-\mathrm{N}\right)$ equilibrium on the process of removing nitrogen by using tubular plastic media. J Mater Environ Sci. 2017;8:4915-22.

Rakocy JE. Ten guidelines for aquaponics systems. 10th Anniversary issue. Aquaponics J. 2007;46:14-7.

Rakocy JE, Masser MP, Losordo TM. Recirculating aquaculture tank production systems: aquaponics-integrating fish 
and plant culture [Internet]. 2006 [cited 2020 May 16]. https://shareok.org/bitstream/handle/11244/319795/oksd_ srac_454_2016-07.pdf?sequence $=1$

Reyes AAD Jr, Lawson TB. Combination of a bead filter and rotating biological contactor in a recirculating fish culture system. Aquacult Eng. 1996;15:27-39.

Robertson LA, van Niel EWJ, Torremans RAM, Kuenen JG. Simultaneous nitrification and denitrification in aerobic chemostat cultures of Thiosphaera pantotropha. Appl Environ Microbiol. 1988;54:2812-13.

Russo RC, Thurston RV, Emerson K. Acute toxicity of nitrite to rainbow trout (Salmo gairdneri): effects of $\mathrm{pH}$, nitrite species, and anion species. Can J Fish Aquat Sci. 1981;38:387393.

Schneider O, Blancheton JP, Varadi L, Eding EH, Verreth JAJ. Cost price and production strategies in European recirculation systems. In: Proceedings of the Linking Tradition \& Technology Highest Quality for the Consumer; 2006; Firenze, Italy.

Spiller H., Dietsch E, Kessler E. Intracellular appearance of nitrite and nitrate in nitrogen-starved cells of Ankistrodesmus braunii. Planta. 1976;129:175-81.

Suh KH, Kim BJ, Jeon IG. Design and development of integrated recirculating aquaculture system. J Korean Fish Soc. 2001;34:70-6.

Thorarinsdottir RI. Aquaponics guidelines. Reykjavik, Iceland: Háskólaprent; 2015.

Tibbetts SM, Lall SP, Anderson DM. Dietary protein requirement of juvenile American eel (Anguilla rostrata) fed practical diets. Aquaculture. 2000;186:145-55.

Zekki H, Gauthier L, Gosselin A. Growth, productivity, and mineral composition of hydroponically cultivated greenhouse tomatoes, with or without nutrient solution recycling. J Am Soc Hortic Sci. 1996;121:1082-88. 